\title{
Histomorphology of the Female Reproductive System of the European Beaver
}

\author{
Teresa DOBOSZYŃSKA
}

\begin{abstract}
Doboszyńska T., 1978: Histomarphology of the female reproductive system of the European beaver. Acta theriol., 23, 5: 99-125 [With 1 Table, 2 Figs \& Plates III-XII].

The structure of the reproductive system of the female European beaver (Castor fiber L in n a u s, 1758), bred in Poland, was worked out by the histological methods and the methods of reconstruction, observation and macroscopic measurements. The age and different physiological conditions of specimens were also taken into account. Observations showed the presence of a well-developed system of corpora atretica and the intensive process, associated with it, of atresia of ovarian follicles, with its intensity falling in the period from the 4 th to the 6 th month of life in the beaver, the occurrence of canalicular structures in the ovaries of newborns and distinct changes in the mucosa of the genital canals, corresponding to the phases of the ovarian cycle. The following features should be mentioned among other ones, as characteristic of the beaver: the development of follicles and corpora lutea in the deep layers of the ovarian cortex, the orifice of the uterine tubes on the medial surface of the horns of uterus, $10 \mathrm{~mm}$ from the top, the specific arrangement of the preputial folds around the clitoris and the scattered accumulations of pigment in this region, the shift of some of the reproductive organs to the "postpelvic" region, and the occurrence of the pseudocloaca. The first corpora lutea, which occur in 6-month-old females, indicate that at this time the sexual cycle has already begun in the ovaries, although the other organs have not developed fully yet. The period from the 4 th to 6 th month of life is a period of both the intensest development and the atresia of follicles. The starting-point of development of the uterine glands is the mucosa of the uterine neck. The union of the uteri into a common segment is particularly well seen in newborns, where the cervical septum, formed of doubled layers of the uterus, loses its external layers gradually as i.t approaches the external orifice.
\end{abstract}

[Inst. Fundament. Vet. Sci., Agric. Tech. Acad., 10-957 Olsztyn, Poland]

\section{INTRODUCTION}

A study on the reproduction of the European beaver in captivity is being carried out in the beaver breeding farms in Poland (D o b o s z y n'ska, 1976a, b, 1977a, b; Ż u rowski \& Doboszyńska, 1975, 1977, b; Żurowski, 1972; Źurowski \& Doboszyńska, 1975, 1976). The continuation of this investigation needs detailed histomorphological data on the reproductive system. There are no comprehensive papers on 
this subject in literature. The monographic publications deal with it only in general terms (D e ž k i n, 1966; H i n z e, 1950).

A number of papers have been published on the biology of reproduction of beavers, but most of the observations presented in them were made on animals living under conditions of natural environment and concern different varieties of the European beaver (D e ž k i n, 1957; 1961; F o m i č eva, 1959; I va nova, 1961) and Canadian beaver (B a y le y, 1927; B e n s o n, 1936; B ond t, 1956; B r a a d t, 1939; B r e nner, 1964; Dalc \& B oskhaut, 1969; Krüger, 1963; Larsen, 1967; Osborn, 1953; Provost, 1962). This is why not all their data hold good for the beaver bred in Poland.

The reports on the biology of reproduction in river beavers from the territory of the Soviet Union indicate that females have offspring once a year, the seasonality of reproduction being distinctly marked (D e žki n, 1957; 1961; F o mi č e va, 1959). As has been shown for females bred at Voronezh ( $\mathrm{L}$ a v r ov, 1954) and those living at liberty (F o mič e va, 1959), the mating season lasts from the beginning of December throughout March, when the symptoms of oestrus and coition may recur at 15-day intervals. In this period Fomič eva (1959) observed large numbers of ripe follicles in the ovaries of females and I vanova (1961) the intensified process of spermatogenesis in the gonads of males. After the mating season, especially in summer, the activity of the gonads decreases up to the complete inhibition of the spermatogenetic process ( $\mathrm{V}$ a n o va, 1961), whereas in females this period is characterized by an increasing number of atretic follicles (F o m i č e va, 1961).

Only Provost (1962) paid attention to the occurrence of Graafian follicles and corpora lutea and albicantia in connection with the number of past pregnancies, using this fact as a criterion in determining the dynamics of a beaver population. However, the insufficient knowledge of the structure of the reproductive system and, consequently, the subjective criteria applied by different authors in their estimation of the inanner of its functioning and also the amphibious ways of life of this animal, impeding observation, caused that contradictory pieces of information were given in most studies. The duration of pregnancy, time of attainment of sexual maturity, causes of the decrease in the size bf beaver populations and cyclic character of ovo- and spermatogenesis were determined on the basis of various factors. Thus, basing himself on secondary factors like skin length, body weight, development of teeth or occurrence of uterine "loops", B r e n ne r (1964) determined that the Canadian beaver attains its sexual maturity at an age of $2-2.5$ years, whereas B a yley (1927) used only body weight as a criterion 
in this respect. Lavrov's (1960) study on the morphological and biological differences between the European and the Canadian beaver indicates the impossibility of crosses between these species. The author puts forward the supposition that this fact may be due to the »thicker ovaries " and the "shortened internal part of the uterus (the distance from the cervix to the ramification of the horns) " in the Canadian beaver. An analysis of the above examples suggests that in none of them the detailed structure of the reproductive system was taken into consideration.

It therefore seems expedient to examine the histomorphology of the reproductive system of the female European beaver bred in Poland as closely as possible, with regard to different periods of its life and, consequently, different physiological conditions. I have decided on giving special attention to the structure of the ovary, which has been preceded by its detailed macro- and micrometric characterization (Dobosz yń ska, 1977b).

\section{MATERIAL AND METHOD}

The animals came from the Experimental Station, Polish Academy of Sciences, at Popielno and the Fur Farm, at Wiertel. They were females, 19 in number, divided into the following groups: (1) newborns -3 , (2) $4-6$ month-olds -5 , (3) $1-3$-year-olds -5 , and (4) above 6 years of age -6 specimens. The last group consisted of 3 pregnant, 2 barren and 1 nursing females. Being healthy animals, they had lost their lives accidentally, i.s. owing to mechanical injury, biting, strangling, etc.

After the genital ducts had been measured and macroscopic observations made, material for fixation and segments for routine examination were taken at defined points (Fig. 1) of the fresh carcasses directly on the farm or after a few hour storage in the frozen chamber. The tissues were fixed with Bouin's fluid, AFA, and Carnoy's fluid for paraffin sections and with neutralized $10 \%$ formol for frozen sections. Sections were stained by a number of methods, chiefly those given in textbooks by $\mathrm{Baginski}$ (1969) and $\mathrm{Zaw}$ is tow ski (1965), according to organs examined and effects desired.

I. Ovaries

1. left - serial sections (about $7 \mu$ thick) stained by Mallory's complex method;

2. right - used to make sections:

(a) for general examination - stained with haematoxylin-eosin,

(b) stained for connective tissue by Mallory's method and a modification acc. to Des Marois and La Hama,

(c) stained with Sudan III and Scarlet $\mathrm{R}$ by Daddy's method or demonstrating fats,

(d) stained for argentophil fibres acc. to Gomori, and

(e) stained by Ralph's method for the demonstration of haemoglobin in order to show the position of blood-vessels in the thecae of follicles and in the ovarian medulla.

II. Uterine tubes. Samples were taken at three points of the left tube: the 
infundibulum, ampulla and isthmus in the region of the uterine orifice and from different regions of the uterine orifice and from different regions of the right uterine tubes. Sections were stained with haematoxylin-eosin, by Mallory's method and with orcein for elastic fibres.

III. Uterus. Samples were taken from:

1. the left horn of uterus - the region including the orifice of the uterine tube and the top of the uterus (serial sections), as well as the middle part of the horn,

2. the right horn of uterus - sections from different regions for general examina_ tion, and

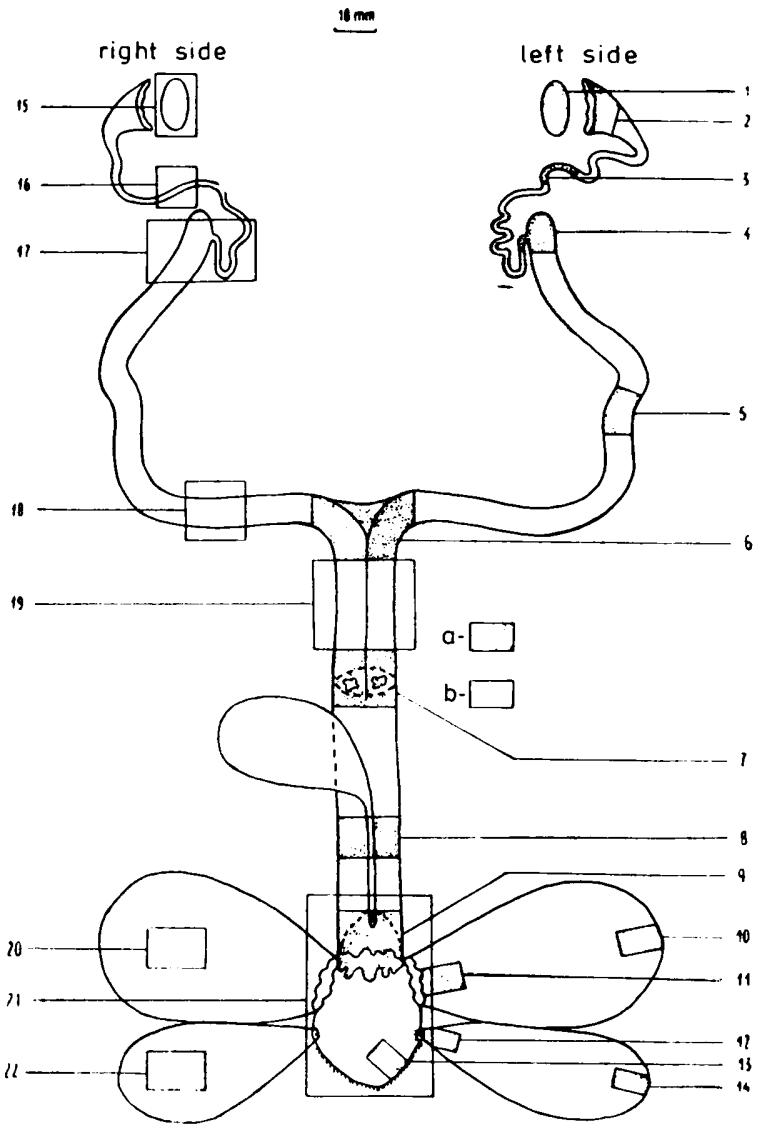

Fig. 1. A diagram showing places in which tissues were sampled.

1-left ovary, 2-infundibulum tubae uterinae, 3-ampulla tubae uterinae, 4isthmus tubae uterina, ostium uterinum tubae and top of left uterus, 5-middle part of horn, 6-region of intercornual ligament, 7 -ostium vaginale uteri and fornix vaginae, 8-middle part of vagina, 9-urogenital sinus in the region of clitoris, 10 -fundus and 11 -orifice of left lateral diverticulum of preputial fossa, 12-orifice of left circumanal gland, 13-pseudocloaca, 14-fundus of circumanal gland, 15 - right ovary, 16-ampulla, 17-terminal loop of uterine tube with top of right uterus, 18-horn of right uterus, 19-middle part of uterine cervix, 20 - lateral wall of diverticulum, 21 - organs of "postpelvic " region, sampled whole in newborns, 22 - wall of circumanal gland.

$a$ - the spaces to receive solid of the sector, $b$ - the preparations review. 
3. the neck of uterus - the region of the intercornual ligament, the middle part and the vaginal orifice (serial sections).

In newborns the whole uterus was sectioned so as to reconstruct the course of particular layers in the wall of the organ (Fig. 2). The staining methods used included haematoxylin-eosin, Gomori's technique for argentophil fibres and orcein for elastic fibres.

IV. Vagina. Samples were taken from the fornix region, the middle portion of the vagina with the underlying urethra, the urogenital sinus and the region of the urethral diverticulum. Sections, $7-15 \mu$ thick, were stained with haematoxylineosin, orcein and, by Gomori's method, and the techniques described by Dob o-

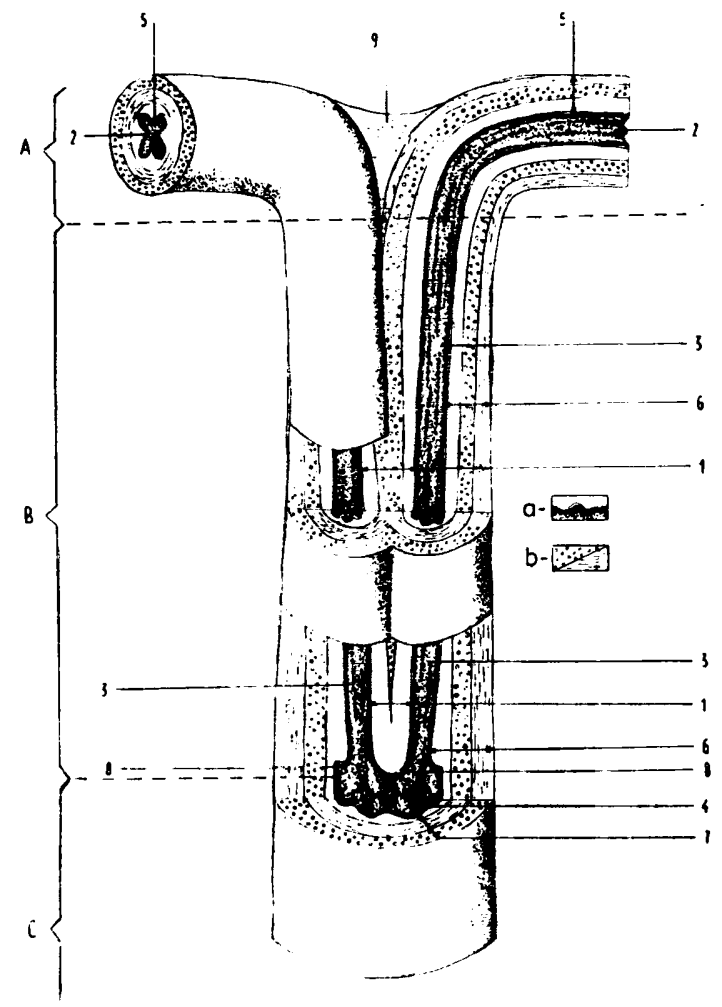

Fig. 2. A diagram of the structure of uterus walls.

A-horns, B - neck, C-vagina, 1-interuterine septum, 2-cavum uteri, 3 canales cervicis, 4-canalis vaginae, 5 - wall of horn, 6 - wall of neck, 7 - wall of vagina, 8 - ostium vaginale uteri, 9 -ligamentum intercornuale.

$\mathrm{a}-$ tunica mucosa, $\mathrm{b}$ - the composition of the stratum musculare.

szyńska (1976) and Krupiński (1955) were used to differentiate the layers of epithelium in the vagina.

V. The clitoris and preputial folds were taken whole and their serial sections were stained by routine methods.

VI. Pseudocloaca. In addition to the routine methods, Dobosz y n s k a's (1976) and $\mathrm{Krupins}$ i's (1955) techniques were also used. 
All the measurements wro made by means of the micrometer and the values given in the text are based on the means from at least 100 measurements.

\section{RESULTS}

\section{Ovary}

The oval cream-white ovaries of the beaver differed distinctly from the adjacent organs and had smooth surfaces; even the ripe follicles or corpora lutea did not bulge very much to the outside. The uterine extremity of the ovary was attached to the uterus by the well-developed ovarian ligament, $10-15 \mathrm{~mm}$ long in the adult females. The facies lateralis faced the capacious, often very fatty ovarian bursa.

\section{Table 1}

Macroscopic measurements of female genital organs in beaver (in $\mathrm{mm})^{1}$. L - length; W - width; T - thickness: In - infundibulum; $A m$ - ampulla; Is - isthmus.

\begin{tabular}{|c|c|c|c|c|c|c|c|c|c|c|c|c|}
\hline \multirow{3}{*}{$\begin{array}{l}\text { Age, } \\
\text { months }\end{array}$} & \multirow{2}{*}{\multicolumn{4}{|c|}{$\begin{array}{c}\text { Oviduct } \\
\text { Width }\end{array}$}} & \multicolumn{5}{|c|}{ Uterus } & \multicolumn{3}{|c|}{ Vagina } \\
\hline & & & & & \multicolumn{3}{|c|}{ Horns } & \multicolumn{2}{|c|}{ Cervix } & \multirow[b]{2}{*}{$\mathrm{L}$} & \multirow[b]{2}{*}{ W } & \multirow[b]{2}{*}{$\mathrm{T}$} \\
\hline & $\mathrm{L}$ & In & $A m$ & $I s$ & $\overline{\mathrm{L}}$ & $\mathrm{W}$ & $T$ & $\bar{L}$ & $\mathrm{~W}$ & & & \\
\hline $2^{2}$ & 15 & 2 & 1 & 1 & 40 & 2 & 1 & 18 & 3 & 40 & 3 & 2 \\
\hline 12 & 15 & 2 & 1 & 1 & 40 & 2 & 1 & 20 & 4 & 45 & 3 & 2 \\
\hline $1^{2}$ & 20 & 2 & 1 & 1 & 60 & 2 & 1 & 25 & 4 & 35 & 3 & 2 \\
\hline 4 & 30 & 3 & 2 & 1 & 86 & 3 & 2 & 23 & 3 & 75 & 10 & 3 \\
\hline 5 & 26 & 3 & 2 & 1 & 80 & 3 & 2 & 30 & 3 & 80 & 6 & 3 \\
\hline 5 & 42 & 3 & 2 & 1 & 78 & 4 & 3 & 30 & 3 & 84 & 6 & 3 \\
\hline 6 & 50 & 5 & 3 & 2 & 75 & 4 & 2 & 35 & 6 & 90 & 6 & 3 \\
\hline 6 & 45 & 5 & 3 & 2 & 75 & 5 & 2 & 35 & 6 & 93 & 6 & 3 \\
\hline 16 & 45 & 5 & 2 & 1 & 113 & 8 & 2 & 40 & 6 & 110 & 16 & 3 \\
\hline 22 & 73 & 16 & 3 & 2 & 152 & 5 & 3 & 55 & 13 & 112 & 23 & 4 \\
\hline 22 & 38 & 5 & 3 & 2 & 106 & 8 & 3 & 35 & 7 & 125 & 15 & 3 \\
\hline 31 & 75 & 8 & 4 & 2 & 115 & 12 & 5 & 40 & 10 & 130 & 25 & 5 \\
\hline 33 & 88 & 10 & 4 & 2 & 184 & 9 & 3 & 56 & 10 & 130 & 10 & 3 \\
\hline $58 \mathrm{P}$ & 83 & 11 & 5 & 3 & 176 & - & $3-5$ & 52 & 16 & 155 & 18 & 4 \\
\hline $69^{\mathrm{P}}$ & 76 & 19 & 6 & 3 & 171 & - & $3-4$ & 55 & 12 & 136 & 19 & 4 \\
\hline $108^{P}$ & 83 & 21 & 7 & 3 & 286 & - & $5-10$ & 90 & 23 & 180 & 26 & 5 \\
\hline $65 \mathrm{~L}$ & 93 & 14 & 6 & 2 & 146 & 8 & 5 & 75 & 15 & 135 & 15 & 4 \\
\hline $72^{S}$ & 81 & 12 & 3 & 2 & 180 & 10 & 4 & 60 & 15 & 140 & 25 & 5 \\
\hline $79 \mathrm{~S}$ & 85 & 12 & 4 & 1 & 154 & 10 & 4 & 45 & 15 & 146 & 20 & 6 \\
\hline
\end{tabular}

1 The values given are means from the measurements of the left and right uterine tubes and horns of uterus.

2 Age in days; $\mathrm{P}$ - pregnant, $\mathrm{L}$ - lactating, $\mathrm{S}-$ sterile.

The ovarian bursa was made up of the externally situated serosa, covered by simple squamous epithelium and overlying a strip of connective tissue with argentophil and collagenous fibres and nuferous smooth myocytes. The middle part was filled with a fatty tissue of big polygonal cells $(80-100 \mu$ in diameter) placed in the fine con- 
nective-tissue stroma. Numerous blood-vessels ran between them. The internal layer was a little thinner and built of connective tissue, similar in structure to that on the external side and also covered by simple squamous epithelium.

The surface of the ovary was covered by simple superficial e pithelium, which in newborns consisted of high columnar cells with big oval nuclei and weakly acidophil cytoplasm. In many places this epithelium penetrated into the ovarian medulla, forming epithelial crypts, shaped as simple or branched tubules. In 4-5-month-old females the crypts occurred sporadically and the superficial epithelium was composed of cubical cells. In older females it was a low pavement or even squamous epithelium. Only in the females whose ovaries were in the follicular phase it consisted of columnar cells of various height and resembled stratified columnar epithelium.

In newborns there was no tunica albuginea yet and it did not appear in females until they were $4-6$ months oid, wiren it formed a relatively thin layer spread on the lateral and medial surfaces $(30-70 \mu)$ and a thicker one in the regions of the poles $(70-100 \mu)$ and the hilus of the ovary $(100-130 \mu)$, where it eniered, together with blood-vessels, into the ovarian medulla. It was made up of plexiform connective tissue, in which collagenous fibres, arranged in all directions and forming "vortices«, occupied the most room. Some of the fibres penetrated into the ovary and consiituted its framework. In addition to the collagenous fibres, there were argentophil fibres, single and in bundles, and single elastic fibres. In older females the tunica albuginea was $100-150 \mu$ thick, in barren females it reached $200-250 \mu$ and in the polar regions of the ovary, even $300-350 \mu$. Only in places where there were ripe follicles under it, the tunica was subtle and thin $(20-30 \mu)$. In barren females a smooth muscular layer occurred in its middle part (Fig. 14). Single myocytes 'were encountered also in the other adult females.

The ovarian cortex of newborns (Fig. 3) was made up chiefly of primary follicles, the largest numbers of which occurred in the vicinity of the ovarian medulla. In the periphery there were remains of the sex cords and, in their extensions, "egg balls", containing repro-juctive cells, some of these last undergoing degeneration. All the elements were set in the fine connective-tissue stroma, which abounded in blood-vessels.

The follicular layer of the ovary of $4-5$-month females was clearly differentiated into two zones, an external, with tightly packed primary follicles, and an internal, containing growing follicles. The primary follicles were arranged in a particularly thick ring in 4-month females, 
whereas in 6-month-olds (Fig. 5) the boundary between these zones was becoming obliterated and the primary follicles were distributed loosely under the tunica albuginea. In the remaining females examined the primary follicles were similarly distibuted, but they were considerably fewer, this being true especially of barren females and a 9-yearold pregnant female, in which they were scarce. In the second, deeper, zone of the ovarian cortex the growing follicles represented all stages of development and some of them showed sings of atresia. Moreover, the first vesicular ovarian follicles occurred in 5- and 6-month females, while in 6-month females there appeared also corpora lutea.

In the group of 1-3-year-old females the ovaries were divided into those obtained from femals that had died in the breding season (January-March) and the ovaries obtained out of this season. In the first case corpora lutea were found present in all the ovaries, which would indicate that ovulation had occurred in various periods of the mating season and even later (female No. 9 died at the beginning of January). On the other hand, one of the two females that had died out of the mating season had its ovaries in the luteal phase, while the ovaries of the other clearly prognosticated the oncoming of ovulation (26 vesicular follicles in the left ovary) (Fig. 6).

The luteal phase in the group of 1-3-year-old famales was marked by the occurrence of $3-4$ corpora lutea, similar in appearance to those in the 6-month females. There were also vesicular follicles $(3-10$ in an ovary) and follicles at early developmental stages. An appreciable part of the ovarian cortex was occupied by corpora atretica and follicles, at various stage of development, affected by atresia.

In the ovaries of the two pregnant females examined (resorption of foetuses) an ovulation that they had freshly gone through was observed in addition to the corpora lutea of pregnancy, which corresponded in number to the foetuses resorbed in the uterus. Some of the corpora haemorrhagica showed partly resorbed blood clots. In the ovarian cortex there were also vesicular follicles, their atretic forms, primary and growing follicles, follicles undergoing atresia and corpora atretica (Fig. 8). The well-seen places of bursting of the follicles situated just below the surface were scarring, and only in some regions irregular shreds of the tunica albuginea were perceptible. Some of the ovulating follicles were situated in the deeper portions of the ovarian cortex and then the way of the egg cell led through the loosened meshes of the connective-tissue network. The walls of these follicles folded and collapsed to a smaller degree than they did in the follicles lying close to the surface.

The presence of two kinds of corpora lutea was observed in the ovaries of the female that had died at the time of parturition. Some of 
them were small, partly fibrotic and distributed in the medial part of the ovarian cortex, while the others, considerably larger and fully developed, lay in the proximity of the ovary surface. Apart from the corpora lutea of pregnancy there were also some old degenerated corpora albicantia, different sorts of follicles, fully developed and undergoing atresia, and corpora atretica. These last occupied much room in the ovarian cortex and constituted distinct morphological elements, characteristic of the ovaries of adult female beavers.

The occurrence of not quite fibrotic corpora albicantia, numerous atretic corpora and follicles, and only single developing follicles (Fig. $7-A)$ is characteristic of the ovaries of nursing females (3 months after parturition).

The ovarian cortex of females that in spite of several attempts to mate had given birth to no offspring during their life had various structures. In one of the females (No. 19), which had died at the age of 79 months, the cortical parenchyma contained only follicles and corpora atretica as well as single primary follicles and small growing follicles. On the other hand, in a 72-month-old female (No. 18) in addition to a large number of atretic corpora and follicles, there were vesicular follicles and corpora albicantia, which clearly indicated the functioning of the ovary.

The primary follicles (folliculus ovarius primarius) had a similar structure in all the females examined and consisted of a row of epithelial cells (9-20 in section), mostly oval, with a large vesicular nucleus, and flat at one of the poles of follicle. The follicle cells clang closely to the oocyte, in which the centrally situated nucleus had a distinct large nucleolus.

The growing follicles (folliculus ovaricus crescens, Figs 15 and 16) were present in nearly all the ovaries. A notable growth of the egg-bearing follicles fell in the period of the 4th-6th month, when the ovarian cortex, differentiated into zones, cosisted chiefly of growing follicles characterized by a certain differentiation, dependent on the degree of their development. An increase in the number of follicle cells was typical of small follicles. Numerous mitotic divisions were observed in them, especially in the follicles with 2-3 layers of granular cells. Centres of accumulation of follicular fluid, in the form of Call-Exner's vacuoles (Fig. 17), were observed in the follicles in which the membrana granulosa was composed of 4-6 layers. In Mallory sections the vacuoles were seen as round red-stained blisters, differing in size. They often contained fragments of cells. The granular cells were marked by their polygonal shape and large round nuclei. In larger folli- 
cles in the theca folliculi, which was built of flaccid connective tissue, (Fig. 16) there were cells similar to the epithelial cells. The reproductive cell, which increased in size with the growth of the follicle, was characterized by a large nucleus. As the reproductive cell grew, the pellucid zone thickened and was particularly well seen as a blue rim in Mallory sections (Fig. 16), which also seemed characteristic.

The vesicular follicles (folliculus ovaricus vesiculosus) were enclosed in the well-developed tunica folliculi $(50-200 \mu)$. The internal tunic was made up of globular, polygonal and spindleshaped cells. In addition to these cells there were also fine connective-tissue fibres, including a network of lattice fibres, and numerous blood-vessels and lymphatic vessels. The external tunic was composed chiefly of collagenous fibres with a circular course, lattice fibres and a few fibroblasts. The stratum granulosum rested on the basement membrane of the follicle and most often consisted of two layers of cells. The cumulus oophorus, characteristic of this type of follicles, was mostly turned to the inside of the ovary. It 'was built of loosely disposed granular cells; a layer of these cells, elongate and cylindrical in shape, clang to the reproductive cell, forming the one-layered or, more rarely, two-layered corona radiata. The pellucid zone, $3-5 \mu$ across, was much thinner here than in growing follicles.

The phenomenon of atresia occurred in all the developmental stages of follicles and gave rise to atretic follicles (folliculi atretici), in which the changes affected both the walls of the follicle and those of the reproductive cell. In primary follicles the signs of atresia were very hard to perceive. Heavily shrunk oocytes were frequently met with, sometimes there were only slight traces of their occurrence and occasionally empty spaces surrounded by a row of follicle cells.

In observing numerous follicles, it was possible to make a close study of the process of atresia in large growing and mature follicles by simultaneous investigation of the serial sections of an ovary and comparison of atretic follicles with those normally developed. The typical changes were the breakdown of the cumulus oophorus and corona radiata and the resulting breach in the contact between the reproductive cell and the granular cells. A large number of fat droplets occurred in the reproductive cell and the nucleus was markedly shrunken or decaying, while the pellucid zone was thick and stained blue or navy blue, like the connective tissue, in Mallory sections. The changes in the reproducive cell, cumulus and corona radiata were often accompanied by some changes in the follicle wall. There were rarely whole cells preserved in the stratum granulosum, more often than not only their 
fragments were seen grouped smear the strongly creased thick hyaline membrane, 'which produced a blue zone surrounding the antrum of the follicle. In such cases the follicular fluid was stained blue with aniline blue by the Mallory method. Then the internal tunic formed a thick ring (Fig. 12), which consisted of round cells resembling the paralutein cells (Fig. 7-B).

The increasing cells of the follicle theca described above overgrew the cavity of the follicle and led to its transformation into a corpus atreticus (Fig. 13). This was separated from the adjacent structures by its own connective tissue sac and, as a result, many whole atretic bodies could be seen preserved in the ovaries of old females. These bodies were spindle-shaped columns compressed in the peripheral portion of the ovarian cortex and smaller oval or round structures situated in its middle portion (Fig. 7-A). In some atretic bodies there was a degenerated reproductive cell, devoid of its corona radiata. Its nucleus was mostly shrunk and resembled a pepper grain, while the abundant accumulations of fat droplets indicated the fatty degeneration of the cytoplasm. Fragments of the hyaline membrane surrounded the declining follicle antrum. Remains of the granular cells only sporadically occurred in its vicinitv.

The arrangement of argentophil fibres in the atretic body parenchyma, centre and theca was also noteworthy (Fig. 4). The fibres round the atretic bodies were thick and gathered into dark-brown stained bundles, they lay circuitously and only their fine hooked branches came off towards the parenchyma. Some of the fibres, having penetrated inside, surrounded single cells or their groups. These fibres were very thin and weakly argentophil. Light-brown, thick and branching fibres occurred in the postfollicular cavity.

The yellow bodies (corpora lutea), occurring in 6-month-old females, were considerably larger than the atretic bodies and differed from them distinctly. The sac that enclosed them contained elements of the follicle theca and it penetrated inside, together with the bloodvessels. The lutein cells which made up the parenchyma were considerably larger than the cells of corpora atretica and were characterized by their oval shape. The cytoplasm contained accumulations of fatty bodies (Fig. 11), which manifested themselves as dark-red droplets in Sudan III sections. In Mallory sections the fats washed away from the cells left empty spaces, giving a frothy appearance to the yellow body. Remnants of fluid and blood clots were observed in the centrally situated cavity of the body.

Similarly structured yellow bodies were present in the group of $1-$ 
3-year-old females, whereas in the older pregnant females they were much bigger and differed somewhat in structure from those described above. Some of them (in females Nos. 14 and 15) were corpora rubra and showed large blood clots inside and, in addition, incompletely scarred places of bursting in the course of ovulation. Elements of this type coincided with the fully developed yellow body of pregnancy (corpus luteum graviditatis) (Fig. 9). The parenchyma of this last was made up of lutein and paralutein cells (respectively, luteocytes and thecoluteocytes), disposed round the fibrous centre. Among the group of cells there was fine connective tissue with collagenous and argentophil fibres. The argentophil fibres, in the form of intertwined bundles, penetrated into the centre, whereas in the parenchyma they ran solely and entwined the cells or their groups. The luteocytes, which were three times as large as the thecoluteocytes, dominated among the cells (Fig. 10). They were arrayed in cords, thus giving the yellow body its radiate appearance. These cells were oval or polygonal, with light-coloured vacuolized cytoplasm and a large vesicular nucleus. While differentiating the fats, we found the occurrence of large droplets throughout the cytoplasm.

The paralutein cells (Fig. 10), situated most frecuently in the peripheral part of the body and penetrating together with the connective tissue into the parenchyma, were characterized by their oval shape and a large oval nucleus with $2-3$ nucleoli.

Vestiges of the yellow bodies, the corpora albicantia, were present in some of the 1-3-year-old females and in the ovaries of the females that had bred the year before. They were characterized by the occurrence of single lutein cells against the background of well-developed connective tissue. The argentophil fibres, which constituted the main component of the connective-tissue stroma, intertwined in various directions, leaving only free meshes in a densely textured network. In the connective tissue of the nursing female there were still "islets" containing glandular cells. The presence of the »islets" with lutein and paralutein cells indicated that the yellow bodies had not atrophied entirely within three months following parturition.

\section{Uterine Tube}

The beaver's uterine tube, a tortuous duct, $45-93 \mathrm{~mm}$ long in the adult females examined, ran in the ventral wall of the ovarian bursa. Its abdominal extremity (about $15 \mathrm{~mm}$ in diameter) expanded into the infundibulum and ended in the ostium abdominalis. The narrowed ampulla of the uterine tube $(1-7 \mathrm{~mm})$ passed together with the wall 
of the ovarian bursa into its dorsal part and, tending towards the backbone, ran under the ovarian ligament to descend backwards parallel to the uterus, forming the final loop behind the bend (about $10 \mathrm{~mm}$ in length). The isthmus of the uterine tube, $1-3 \mathrm{~mm}$ long, opened into the uterus at the orifice of the uterine tube, at a distance of about $10 \mathrm{~mm}$ from its top.

Except in the newborns, the mucous tunic had numerous longitudinous folds with fine secondary and tertiary branches. In consequence, the lumen of the uterine tube resembled a labyrinth. The folds were low and did not branch in the isthmus (Fig. 20), reached the greatest size in the ampulla (Fig. 21) to decrease in size again in the region of the funnel and pass into a smoothly ended edge without producing any fringes.

The musculartunic consisted as a rule of two layers of smooth muscle fibres, an internal (stratum circulare) and an external (stratum longitudinale). The muscular tunic was best developed in the isthmus (this is especially true of the circular layer), while in the ampulla both the longitudinal layer and the circular decreased gradually. The layers could not be distinguished in the wall of the thin funnel, where there were only single myocytes, which had a tendency to a circular course.

The seroustunic had a structure typical of the peritoneum.

The internal structure of the uterine tube, notably that of the mucosa, showed some differences, which were dependent upon the age and the physiologic state of the ovary. In the newborns (Fig. 18), in which only the funnel was distinguishable and the other segments were thin and poorly developed, the walls had a similar structure all over their length. They were built of a poorly marked mucosa - covered by a simple columnar epithelium - single myocytes and thin serosa. The epithelium of the mucosa consisted of cells with oval nuclei placed at the same level in the light-coloured cytoplasm. Numerous dividing cells were observed both in the epithelium and in the connective-tissue stroma.

In the funnel of the well-developed uterine tubes the 4-6-monthold females (especially 6-month ones) had a folded mucosa, which decreased in size towards the ampulla. The epithelium of the mucosa was made up of slim cells, which clung closely to each other and whose cylindrical nuclei occurred at the same level (Fig. 20). In the folds of the mucosa there was a compact texture of fibres, which became somewhat looser the nearer it approached the muscular layer. It was only as far as the ampulla that the muscular membrane appeared and had the form of circularly arranged fibres to differentiate into layers in the isthmus (Fig. 20). 
In females Nos. 12 and 18 (Table 1), whose ovaries were at the follicular stage, the uterine tubes were characterized by their thick and swolien mucosa. The folds were high and branched over the whole length of the organ, as if budding into its lumen. They were covered by a high epithelium $(35 \mu)$ of evently outlined cells, most of which were ciliated. There were no visible granulations in the cytoplasm and the nuclei were high and cylindrical. The mucosa propria, showing dense texture, especially that of collagenous fibres, and the tela subserosa made up of delicate flaccid connective tissue with a welldeveloped network of blood-vessels, were distinguished in the mucous membrane.

The uterine tubes of the females whose ovaries contained corpora lutea (both unpregnant 1-3-year-old females and pregnant or nursing ones) had similar structural features. The low folds of mucosa were covered by a low epithelium $(15-20 \mu)$ with an uneven surface edge in section (Fig. 19). Some of the cells were oval and ciliated and their nuclei were placed close to the base, the others were nail-shaped, their tapering bases reached the basement membrane and the widened tops with triangular nuclei projected somewhat above the surface. The cells thus arranged resembled stratified epithelium. The mucosa, low at that time, contained elastic fibres. Small differences that could be observed in the structure of the uterine tubes of particular females involved the height of epithelium, the number of nail-shaped cells and the appearance of leucocytes in the connective tissue at the base of the mucosa.

\section{Uterus}

The double uterus of the beaver consisted of two uteri, the cavities of which were quite independent of each other. It was characterized by two 'well-developed free segments, suspended from the well-vascularized mesometrium and fastened by the intercornual ligament in the place of junction into a common section corresponding to the double cervical canal of the uterus. The cervical canals were separated by a septum, which protruding into the vagina, divided two fissural external orifices of the uteri. The vaginal part of the cervix protruded in the form of a 15-millimetre infolding. The uterine neck, the walls of which were considerably thicker than those of the horns and hard to the touch, constituted about a quarter of the overall length of the uterus in unpregnant females. The mild passage of the neck into the horns made it impossible to distinguish the internal orifice of the uterus.

In outline, the walls of the horns (Fig. 2) were composed of the endometrium, with numerous longitudinal folds, the myometrium, divided into a circular layer and a thinner longitudinal one, and the 
perimetrium. All the layers were uniformly spread all along the horns. Only in the region of the orifice of the uterine tube, arching cephalad, they formed, a blindly ended top to narrow $15 \mathrm{~mm}$ from the top on the margo mesometrium side and pass into the isthmus of the uterine tube. At the height of the intercornual ligament the median walls of the uteri approached each other and the particular layers remained distinct, the longitudinal muscular membrane becoming thinner and thinner. Further, in the cervical septum the longitudinal muscular layers vanished entirely and were no longer present at one-third of the height from the horns. Instead, there was a strip of connective tissue separating the circular muscular layers, which maintained their distinctness up to two-thirds of the length of the neck, where they began to narrow and disappeared without reaching the end of the septum. In the region of the external orifice of the uterus the septum consisted only of the mucous membrane, which on the ventral side grew together with the wall of the vagina and formed a thick fold.

The thin walls of the uterine horns in the newborns (Fig. 22) consisted of the mucosa, $50-300 \mu$ thick, circular muscular membrane, $30-50 \mu$, underlying vascular layer with the longitudinal muscular layer, $20-40 \mu$, and the serous membrane. In all the newborns on the mesometrium side the mucosa formed a single characteristic fold (about $300 \mu$ ) (Fig. 22-A). The epithelium of the mucosa (Fig. 22-B), $15-20 \mu$ thick, was built of ciliated spindle cells. Their weakly stainable cytoplasm contained large oval nuclei, distributed at various levels, which made the epithelium similar to the stratified one. A similarly structured epithelium covered the mucosa of the neck. In the horns there were no uterine glands, their buds appeared only as far as the neck (Fig. 24). All over the length of the horns the mucosa was composed of flaccid connective tissue with a very rich network of bloodvessels. The fibrous stroma consisted of collagenous and argentophil fibres, which were chielfy connected with the walls of vessels and the subepithelial region. Among the cells of the connective tissue fibroblasts, lymphocytes and large numbers of cells resembling the mesenchymal cells of germinative connective tissue were distinguished by the staining methods employed. Division was observed in many cells.

In the newborns the somewhat lower mucosa of the neck developed numerous folds, which gave the lumen of the cervical canals its irregular outline. The number of folds increased towards the external orifice of the uterus and with them increased the number of the cervical uterine glands. The largest numbers of these glands occurred at twothirds of the height of the cervical septum and in the region of the external orifice. Some of the glands were shaped like short canules, 
others had a vesicular st ne; in the septum some of them were coiled. The glandular epithelium differed $f_{\iota} \cup m$ the superficial epithelium in the height of cells $(10 \mu)$ and the basal position of nuclei, which emphasized its one-layered nature (Fig. 24).

The uteri of 4-6-month-old females did not differ much from each other (Table 1). The occurrence of a large number of glands only in the mucosa of the horns and the distinct differentiation of the mucosa into the functional and the basal layer of the endometrium were noteworthy. This was particularly well seen in 6-month females, in which, in addition, a compact and a spongy layer could be distinguished in the functional layer. The differentiation into particular layers was distinct chiefly in the lateral walls of the horns, whereas a large fold of mucosa situated on the mesenteric side showed, besides a large number of glands, a uniform density of connective tissue elements. The superficial and glandular epithelia consisted of large columnar cells $(20-25 \mu)$, evenly arranged on the thick basement membrane. The cylindrical nuclei reached under the surface of the cells. In the lumen of the glands there were small amounts of secretion, which was stained intensely with aniline blue. The structure of the neck was characterized by lack of the glands, the abundant blood supply of the mucosa, the low simple epithelium $(10 \mu)$ and the dfiferentiation of the mucous membrane into the compact and the spongy layer (Figs. 23-A and 23-B). The muscular layer was well-developed both in the horns and in the neck, and it was marked by the particularly light arrangement of muscle fibres in the circular layer (Fig. 30). The vascular layer contained large vessels, especially in the 6-month females, which penetrated between the bundles of muscle fibres.

In the group of $1-3$-year-old females the structure of the uterus, like that of the uterine tube, showed its dependence on the functional state of the ovary. In female No. 12 (follicular phase of ovary) the swollen mucosa, the folds of which, $2400-3500 \mu$ in height, limited the fissural lumen of the cavities of the uteri, was furnished with huge numbers of glands in the form of straight or winding narrow canules, which reached the basement membrane (Fig. 25-A). The columnar glandular cells $(30 \mu)$ and those epithelium of the mucosa $(20 \mu)$ did not bear any signs of secretion and were built in a similar manner. Small numbers of glands were also present in the first section of the neck.

In the other females of this group (luteal phase of ovary) the mucous glands of the horns were low, oval in section, with much secretion inside (Fig. 25-B). The cells of the glandular and superficial epithelia had strongly vacuolized cytoplasm and their nuclei were distributed 
. at various levels. Cellular fragments were often present in the then profuse secretion of the glands and in the u's ine cavity. A characteristic feature of the connentive tissue stroma was the great density of icells in the superficial portion of the mucosa. These cells were large, oval and resembled the epithelial cells in structure. There were lymphocytes among them. The other layers of the ureter did not differ from those described above.

The uterine horns of the pregnant females, considerably enlarged during pregnancy (Table 1), were characterized by the well-developed functional layer of the mucosa, the rich vascularization and the occurrence of numerous glands, whose structure varied from female to female.

In the females with the resorption of foetuses the glands had a tortous course and narrow lumen with a small amount of secretion in it. The glandular and epithelial cells of the mucosa, similar in structure and height $(30-35 \mu)$, were ciliated and had big cylindrical nuclei placed close to the base. Similar glands occurred also in the first section of the uterine cervix.

In all the pregnant females the muscular membrane all over the mucosa was preseved complete, the epithelium was relatively low $(10 \mu)$ and composed of large $(25 \times 10 \mu)$ oval cells, lying flat on the basement membrane. They had light-coloured, weakly stainable cytoplasm and large oval nuclei, with $2-3$ nucleoli each. The remaining cells were spherical with small nuclei. The uterine glands, small at that time, were built of almost flat cells with lightly vacuolized cytoplasm (Fig. 25-C). Most of the glands looked as if they were atrophying. Some of them contained residual mucus. Single glands occurred also in the mucosa of the neck, especially in its septum.

In all the pregnant females the muscular membrane all over the uteri was characterized by the compact arrangement of long muscle fibres in the circular layer, the presence of thick bundles in the longitudinal layer, and the occurrence of a large number of elastic fibres.

The uterus of the nursing female had thin walls, whose mucosa was covered by a typical simple columnar epithelium without signs of secretion. At that time in the epithelium of the mucosa the atrophic uterine glands of similarly structured cells and with secretion remains in their lumina occurred chiefly in the middle part of the uterine horns. Only single elastic fibres were present in the connective tissue stroma.

The uteri of the sterile females differed in structure. In female No. 19 the short (Table 1) and thin horns were marked by the fibrosis of the mucosa and the decay of its glands and epithelium. Epithelial cells and their fragments filled the interiors of the glands, which were 
also penetrated by connective-tissue fibres. The proper layer of mucosa was formed of densely packed fibres and only single scattered fibroblasts. On the other hand, the uterus of female No. 18, with the markedly swollen mucosa of the horns and numerous glands, in structure resembled the phase of growth in female No. 12. As in that case, the distri'bution of glands was extended over the cervical septum.

\section{Vagina}

The vagina was a tubular organ, ranging in length from $35 \mathrm{~mm}$ in the newborns to $180 \mathrm{~mm}$ in the adult females (Table 1), two-thirds of which was situated in the pelvic cavity and one-third in the "postpelvic " pegion. On the dorsal side it formed the dorsal fornix in the region of the uterine neck and on the ventral side joined the cervical septum to produce an extension in the form a thick fold. The terminal segment of the urogenital sinus, $15-20 \mathrm{~mm}$ long, opened together with the anus into the pseudocloaca. In the newborns the external orifice of the urethra was already situated within the funnel-shaped diverticulum urethrale vestibuli vagine and the female urethra coalesced with the ventral wall of the vagina and, over a short distance, with the crura clitoridis.

The thin wall of the vagina in the newborns, showing the same structure all over its length, was lined by mucosa with a smooth foldless surface. The structure of epithelium resembled that in the uterus. Its 30-micron-high cells with big vesicular nuclei were arranged in the same way as they were in the epithelium of the uterus at various levels and their cytoplasm was intensely cyanophil. The well-vascularized mucosa had no glands. Numerous fibroblasts, lymphocytes and mesenchymal cells were observed in the connective tissue. Most of the fibrous elements were collagenous fibres. The argentophil fibres were connected with the vessel walls and the basement membrane. The mucosa, thus structured, lined also the urogenital sinus and diverticulum urethrale. The muscular membrane was made up to smooth myocytes, the multidirectional arrangement of which did not permit the distinction of layers.

The much better developed mucosa of the vagina of the $4-6$-month females formed longitudinal folds. In the region of the vaginal part of the uterus the simple columnar superficial epithelium ( $25 \mu$ high), passing graidually, on to the fornix of the vagina, changed into a stratified epithelium $(25-60 \mu)$ of diversiform cells. In the 4-month female numerous cell divisions were observed where the epithelium was lowest, one- or two-layered in some places (in the region of the fornix, Fig. 26-A). In the 5- and 6-month females the epithelium was composed 
of 2-4 layers of cells, which showed various affinities to stains. The cytoplasm of large flat superficial cells was acidophil (eosin, orange G), whereas in the cells of lower layers, especially those of the germinative layer, it was cyanophil (light green). The superficial cells were most often devoid of nuclei or their nuclei were pycnotic, while in the cells of the deeper layers the nuclei were of a vesicular shape and their staining with neutral red varied with $\mathrm{pH}$. The epithelium, built like that, passed from the vagina on to the walls of the diverticulum urethrale, clitoris and its folds, and showed a tendency to the multiplication of layers, whereas in the region of the urethra it assumed the form of a transitional epithelium.

In the 4-6-month-old females the mucosa of the vagina, differentiated into a superficial and a basal layer, was made up of connective tissue with a dense texture of fibres and condensation of cells in the superficial portion (Fig. 26-B). Elastic fibres appeared in it and condensations of lymphocytes were visible under the epithelium. The basal layer was loosely woven and contained many blood-vessels. The adjoining muscular coat was divided into an external layer of longitudinally extending myocytes and an internal circular layer.

In the 1-3-year-old females the distinct phase of growth of the mucosa in the vagina was found only in female No. 12. Growth was chiefly seen in the epithelium, in which there were 5-10 layers of cells (Fig. 26-C). The mucosa of the whole vagina was swollen, it formed longitudinal folds, and its texture was loose both in the superficial layer and in the basal. In the remaining females of this group (luteal phase of ovary), however, the vaginal epithelium was low, it consisted of $2-3$ layers of similarly built cells with exceedingly cyanophil cytoplasm, and the superficial layer of mucosa showed a dense texture of fibres (chiefly elastic ones). A somewhat thicker epithelium (4-5 layers), with a tendency to keratinization, occurred only in the terminal segment of the urogenital sinus.

In the pregnant females with their foetuses under resorption a very thick whitish, hard to the touch, lining was shown in the lumen of the organ even at macroscopic examination; coming off in some places, it resembled »wall paper «. Microscopically, this lining consisted of keratinized epithelial cells, which had intensely eosinophil cytoplasm and were stuck together manifoldly (Fig. 26-D). Such distinct proliferation of the epithelium took place not only in the vagina but also in the urogenital sinus and diverticulum urethrale.

As regards the female that had died during parturation, the walls of the vagina were lined with an epithelium of $4-5$ layers of cells with cyanophil cytoplasm and in the connective-tissue stroma there were 
many lymphocytes, especially small ones, which penetrated the epithelium and gathered in the vaginal secretion.

In the period of lactation the mucosa of the vagina, with low and very fibrotic folds, was covered by a $2-3$-layered epithelium of nonkeratinized cells. Only in the urogenital sinus and its diverticulum urethrale it consisted of 4-6 layers.

Out of the two females, regarded as sterile, only the structure of the vagina in female No. 19 seemed to confirm this fact. Its very thin, completely fibrotic and foldless mucosa was covered by $2-3$ layers of deformed, shrunken and even decaying cells. On the other hand, the structure of the vagina in female No. 18, like that of female No. 12, clearly indicated the phase of growth.

\section{Pseudocloaca}

Present in all the females examined, the pseudocloaca was lined with hairless skin, the corium of which produced numerous papillae and the epidermis was a typical keratinizing stratified squamous epithelium (Fig. 30). The corium and lightly marked subcutaneous layer had a typical structure. Under them there was a layer of cross striated muscules.

\section{Clitoris}

The urogenital sinus, opening ventrally in the pseudocloaca, ended in the clitoris, whose glans clitoridis, $3-5 \mathrm{~mm}$ long, projecting into the preputial fossa, was surrounded by multiple rugged whitish folds. Especially two folds, situated laterally, were well developed. On the ventral side the folds formed a characteristic »collar", above which dark pigmentation was visible in all the females (Fig. 28). Both the glans and the preputial folds were covered by a thick stratified squamous epithelium, which was subject to keratinization and desquamation (Fig. 29-A). In the cells of deeper epithelial layers there were profuse pigment granulations. The corpora cavernosa clitoridis surrounded by the albugineous tunic occurred in the substratum of the glans (Fig. 27), corpus and crura clitoridis, tightly woven of elastic fibres (Fig. 29-B).

\section{DISCUSSION}

The development of the ovaries and genital canals of female beavers is not completed at the time of their birth. Previous studies on the build and origin of the epithelial crypts and canalicular structures in the 
ovaries of newborns indicate that the presence of these elements is connected with the formation of the sexual cords, and their remnants in 4-6-month-old females suggest that the process of differentiation and maturation of the gonads is still under way (Doboszynska, 1977a). In the light of the present observations the division of the ovarian cortex into the zones of primary and growing follicles and then the obliteration of the boundary between them, the disappearance of the crypts, canaliculi and »egg balls", the production of the albugineous tunic and the changes in the formation of the superficial epithelium of the ovary point to the fact of differentiation of the cortex up to the sixth month of life. During these 6 months nearly half the number of primary follicles are resorbed (Doboszynska, 1977b), it comes to the intense development of many growing follicles and, in addition, many follicles at different stages of development undergo atresia. At the same time it comes to the production of the first ripe follicles and corpora lutea, which would indicate the outset of the function of ovaries, although the measurements (Doboszynska, 1977b) and the structure of the corpora lutea of 6-month females differ from those of the corpora in older females.

The results obtained during my study of the beaver's ovary seem to confirm Mossman's (1967) observations made on the basis of many species not only of laboratory rodents but also of those running wild, especially Sciuromorpha, which include the beaver. He emphasizes the fact that in the infantile ovaries of rodents the follicles arising from the medullary cords develop first. The ovaries of newborns and 4-6-month females observed by me showed a distinct division into follicular zones, of which the one situated medially contained growing follicles, probably arising from the medullary cords. During the maturation of the ovary the development and atresia of follicles occur simultaneously and result in the formation of the secondary tissue of the interstitial gland in many rodents (M os sman, 1967). In the beaver this gives numerous atretic bodies and, owing to the well-preserved connective tissue of the internal theca of the follicles from which they have arisen, permits them to remain distinct in the medulla.

On the basis of her observation of the ovaries of free-living beavers. F o mic eva (1959) states that the follicles that have entered upon the phase of development are present in 1-year-old females and that the ripe follicles do not occur until the females are 2 years old. For this reason she thinks that some of the 2-year females are fit for reproduction in this period, although the analysis of the reproductive organs carried out by her indicates their maturation up to the 3rd year of life. However, she admits that the reproductive organs may 
mature earlier than in 1-year-old females. My own observations show that in beavers bred in Poland the ovaries ripen somewhat earlier and the presence of corpora lutea in 1-3-year-old females in various seasons of the year points to the fact that the ovarian cycles may occur also out of the normal mating season.

As in the ovary, a number of changes in growth and development were observed in the genital canals. This is, above all, true of the mucosa, which both in the uterine tube, uterus and in the vagina thickened and folded and whose layers differentiated with age. Judging from the material examined, the genital organs are already entirely formed in the sixth month, but complete maturation is attained at the age of $1-3$ years, when the changes observed in the genital organs are dependent on the function of the ovary. This is evidenced by the changes in the mucosa of the uterine tubes, the functioning of the uterine glands and, especially, the proliferation and keratinization of the superficial layers of the vaginal epithelium, typical of rodents and conditioned by the phases of the oestrus cycle. A close study of the oestrus cycle carried out by Doboszyńska \& Żurowski (1976a) has confirmed these observations. The production of a thick epithelial layer, a sort of "wallpaper " of the vagina, described in the present paper, together with the appearance of corpora lutea beside corpora rubra in the ovaries of pregnant females with the resorption of foetuses not only proves that ovulation and oestrus occurred in them but also confirms the possibility of superfoetation found in this species earlier ( $Z$ urowski \& Doboszynska, 1975). On the basis of his observations of beavers bred in cages in Finland, Kr üg e r (1963) states that a number of epithelial pads appear in the vagina of females in oestrus. During copulation they are poured over with seminal fluid and get outside in the form of white plugs.

Independently of the phases of the vaginal cycle the epithelium which lines the terminal segment of the genital canals, chiefly the pseudocloaca, clitoris and its region, undergoes keratinization. The organs of this segment, together with the anus, circumanal glands nad castoreumproducing diverticula are within the range of the postpelvic region and, according to $\mathrm{Nikulin}$ (1954) and Gienc \& Doboszynska (1972), are a character resulting from the adaptation of beavers to the amphibian ways of life.

The baggy diverticula of the preputial fossa region, characteristic of beavers and topographically and functionally associated with the reproductive system, were interesting not only to the gatherers of castoreum as an unfailing medicine for many ailments. Kacniels on \& Orlova $(1954,1956)$ and Doboszyns a $(1976 \mathrm{~b})$ dealt with the 
structure of these organs. They agree that these diverticula are organs formed by the infolding of the lateral walls of the preputial fossa and are not glands; their products are formed from epithelia contained inside them by maceration and a number of chemical processes occurring under the influence of urine, remains of food and also plant seeds which get into them.

\section{REFERENCES}

1. Bagiński S., 1969: Technika mikroskopowa. Państw. Wyd. Nauk.: 1-708. Warszawa.

2. B a yley V., 1927: Beaver habits and experiments in beaver culture. U. S. Dept. Ag. Tech. Bull., 21: 1-39.

3. Benson S. B., 1936: Notes on the sex ratio and breeding of the beaver in Michigan. Univ. Mich. Mus. Zool. Occas. Papers, 6: 335-341.

4. Bondt F., 1956: Correlations between reproductive condition and skull characteristics of beaver. J. Mammal. 37, 4: 506-512.

5. B r a d t G., 1939: Breeding habits of beaver. J. Mammal., 20, 4: 486-489.

6. Brenner F. J., 1964: Reproduction of the beaver in Crawford County Pensylvania. J. Wildl. Manage., 28, 4: 743-747.

7. Dalc H. B. \& Boskhaut T. A., 1969: Reproductivity of beavers in north-eastern Ohio. J. Wildl. Ursah. Manage., 33, 4: 927-932.

8. Dežkin V. V., 1957: Akt sparivanija u rečnyh bobrov. Tr. Voronež. Gos. Zap. 7: 225-228.

9. Dežk in V. V., 1961: Ves rečnych bobrov Voronežkoj populjacii. Tr. Gos. Zap., 12: 89-105.

10. Dežkin V. V., 1966: Biologija i hozjajstviennoe ispolzovanie bobra. Izd. Ekonomika: 1-89, Moskva.

11. Doboszyńska T., 1976a: A method for collecting and staining vaginal smears from the beaver. Acta theriol., 21, 22: 299-306.

12. Doboszyńska T., 1976b: Strój bobrowy (Castoreum). Wszechświat, 1: 8-10.

13. Doboszynska T., 1977a: Histologic observations on the structure and origin of epithelial crypts and canalicular structures in the ovary of the Eurcpean beaver (Castor fiber L., 1758). Folia morphol. (Warszawa), 36: 23-27.

14. Doboszynska T., 1977b: A macrometric and micrometric description of the ovary in the European beaver. Acta theriol., 22, 18: 261-270.

15. Doboszyńska T. \& zurowski W., 1975. Changes observed in the reproductive tract of a beaver female after high dosages of gonadotropic hormones. Acta theriol., 20, 8: 105-112.

16. Doboszyńska T. \& Żurowski W., 1976: Vaginal smears during a sexual cycle of the beaver. "Comunication Abstracts" VIIIth International Congress on Animal Reproduction and Artificial Insemination: 68, Kraków.

17. Doboszyńska T. \& zurowski W., 1977: Cytologic indices and their applications in evaluation of vaginal smears in the European beaver (Castor fiber L.). Folia morphol. (Warszawa), 36: 235-244.

18. Fo mi ̌̌ v a N. J., 1959: Rozmnoženie rečnogo bobra. Biull. mosk. Obšc. Ispyt. Priv., Otd. Biol., 14, 3: 5-15.

19. Gienc J. \& Doboszyńska T., 1972: Macromorphological description of the genital organs of the female beaver. Acta theriol., 17, 30: 399-406.

20. Hinze H., 1950: Der Biber. Akademie V.: 1-214. Berlin. 
21. I vanova T. M., 1961: Godovaja cykličnost spermatogeneza rečnogo bobra. Tr. Voronež. Gos. Zap., 12: 117-138.

22. Kacnielson Z. S. \& Orlova I. I., 1954: Gistologičeskoe stroenie tak nazyvaemyh prepusjalnyh (muskusnyh) želez vzroslogo rečnogo bobra. Ib., 5: $58-63$.

23. K a c nielson Z. S. \& Orlova I. I., 1956: Razvitie prepucjalnyh "želez" bobra. Ib., 6: 67-72.

24. K r üger F., 1963: Paarung und Seksualzyklus als wahrscheinliche Ursache der Spätherbst- und Winterwürfe beim auggesetzten Kanada-Biber (Castor canadensis $\mathrm{Kuhl}$, 1918) in Finland. Säugetierkundl. Mitt., 1: 16-20.

25. Krupiński L., 1955: Nowa metoda barwienia rozmazów pochwowych. Folia biol., 3: 275-294.

26. Larson J. S., 1967: Age structure and sexual maturity within a western Maryland beaver (Castor canadensis) population. J. Mammal., 48, 3: 408-413.

27. Lavrov L. S., 1954: Biologičeskoe i zootehničeskoe obosnovanie razvedenija bobrov na ferme. Tr. Voronež. Gos. Zap., 5: 7-25.

28. Lavrov L. S., 1960: $K$ voprosu biologičeskih i morfologiĉeskih različjah mieždu evropejskimi i kanadskimi bobrami. Ib., 11: 103-120.

29. Mossman H. W., 1967: The rodent ovary. Comparative Biology of Reproduction in Mammals. Symp. zool. Soc. London, 15: 455-470.

30. Nikulin W. N., 1954: „Pozaditazovaja oblast « rečnogo bobra. Tr. Voronež. Gos. Zap., 5: 56-59.

31. Osborn D. J., 1953: Age classes, reproduction and sex ratios of Wyoming beaver. J. Mammal., 34: 27-44.

32. Provost E. E., 1962: Morphological characteristics of the beaver ovary. J. Wildl. Manage, 26, 3: 272-278.

33. Z a wist ow ski S., 1965: Technika histologiczna oraz podstawy histopatologii. Państw. Zakł. Wyd. Lek.: 1-471. Warszawa.

34. Żu rowski W., 1972: Wstępne doświadczenia nad regulacją rozrodu bobrów. Mat. XII Zjazdu PTF.: 290-291. Olsztyn.

35. Zurowski W. \& Doboszyńska T., 1975: Superfoetation in European beaver. Acta theriol., 20, 7: 97-104.

36. zurowski W. \& Doboszyńska T., 1976: Induction of ovulation in beaver outside the normal breeding season. "Comunication Abstracts" VIIIth International Congress on Animal Reproduction and Artificial Insemination: 292. Kraków.

Accepted, July 20, 1977.

Teresa DOBOSZYŃSKA

\section{HISTOMORFOLOGIA SAMICZEGO UKEADU ROZRODCZEGO BOBRA EUROPEJSKIÉGO}

\section{Streszczenie}

Za pomoca metod histologicznych, rekonstrukcji graficznych oraz obserwacji i pomiarów opisano budowę układu rozrodczego samic bobra europejskiego, hodowanych na fermach w Polsce, $z$ uwzględnieniem ich wieku i różnych stanów fizjologicznych. 
Do charakterystycznych cech występujących u bobra można zaliczyć: zróżnicowanie warstwy korowej jajnika samic 4-6 miesięcznych na strefę pęcherzyków pierwotnych i wzrastających oraz tendencje do dojrzewania pęcherzyków jak i powstawania ciałek żółtych w części przyśrodkowej kory, a przez to zawsze gładkie powierzchnie jajnika; ujście jajowodów na przyśrodkowej powierzchni rogów macicznych $w$ odległości $10 \mathrm{~mm}$ od jej wierzcholkach; występowanie w macicy specjalnego fałdu śluzówki, w którym u samic ciężarnych wytwarzane było łożysko; specyficzny układ fałdów napletkowych wokół łechtaczki oraz rozproszone sk’. piska pigmentu w tej okolicy; przesunięcie części narządów rozrodczych w okolicę „zamiedniczną" i wytworzonie niby-steku, do którego oprócz zatoki moczowo-płciowej i odbytu uchodziły zachyłki boczne dołu napletkowego i gruczoły przyodbytowe.

Pierwsze ciałka żółte występujące u samic 6 miesięcznych wskazywały, że w tym okresie zostal zapoczątkowany cykl płciowy, pomimo, iż pozostałe narządy nie osiągnęly jeszcze pełnego rozwoju. W wyniku przeprowadzonych badań stwierdzono silnie rozbudowany układ ciałek atretycznych i wiążący się z nim intensywny proces atrezji pęcherzyków jajonośnych, których nasilenie występuje u samic 4-6 miesięcznych, obecność struktur kanalikowych w jajnikach noworodków, wyraźne zmiany w blonie śluzowej jajowodów, macicy, a szczególnie pochwy (keratynizacja nabłonka) odpowiadają poszczególnym fazom cyklu jajnikowego. U samic 1-3 lat narządy dróg rodnych były w pełni rozwinięte, a występowanie fazy lutealnej jajnika w różnych okresach roku wskazywało na możliwość zapłodnienia samicy poza sezonem godowym.

Punktem wyjścia dla rozwoju gruczołów macicznych jest sluzówka szyjki macicznej. Polączenie się macic w odcinek wspólny szczególnie dobrze widoczne jest u noworodków, gdzie przegroda szyjkowa utworzona jest ze zdwojonych warstw macicy w miare zbliżania do ujścia zewnętrznego zatraca stopniowo warstwy zewnętrzne.

\section{EXPLANATION OF PLATES III-XII}

\section{Plate III}

Fig. 3. Fragment of cortical layer of ovary in newborn. Mallory, $\times 500$.

1 - primary follicles, 2 - egg ball $\kappa$.

Fig. 4. Argentophil fibres in atretio corpus. Gomori, $\times 200$.

Fig. 5. Ovary of 6-month-old female. Intense development of follicles. Mallory. $\times 25$.

\section{Plate IV}

Fig. 6. Cross section through ovary of 31-month-old female (No. 12)-follicular phase. Mallory, $\times 25$.

Fig. 7. Ovary of nursing female: A-section in which atretic bodies prevail $(\times 16), \mathrm{B}-$ cells of atretic body $(\times 800)$, Mallory.

\section{Plate V}

Fig. 8. A picture of the ovary of a pregnant female with the resorption of foetuses. Mallory, $\times 12.5$.

1 -corpus luteum, 2-corpus rubrum, 3-follicles, 4-corpora atretica. 
Fig. 9. Corpus luteum of pregnancy. Mallory, $\times 63$.

Fig. 10. Cells of corpus luteum of pregnancy. Mallory, $\times 800$.

1 - luteocyte, 2 - paraluteocyte.

Fig. 11. Corpus luteum of ovary of 6 -month-old female. Sudan III, $\times 125$.

\section{Plate VI}

Fig. 12. Fragment of ovary of nursing female. Mallory, $\times 63$.

1 - advanced atresia in ripe follicles, 2 - corpus atreticum.

Fig. 13. Corkus atreticum. Degenerated reproductive cell visible in postfollicular cavity. Mallory, $\times 200$.

\section{Plate VII}

Fig. 14. Ovary of sterile female - section in ovarian pole region. Mallory, $\times 30$. 1 -tunica albuginea, 2-medullary layer, 3-cortical layer, 4-concentration of smooth muscle fibres.

Fig. 15. Fats in growing follicle. Sudan III, $\times 500$.

Fig. 16. Growing follicle. Mallory, $\times 500$.

1 -reproductive cell, 2 - nucleus, 3 -nucleolus, 4-zona pellucida, 5-granular cells, 6 - follicular theca with big epithelioid cells.

Fig. 17. Call-Exner vacuoles in growing follicle. Mallory, $\times 800$.

\section{Plate VIII}

Fig. 18. Uterine tube of a newborn. Haematoxylin-eosin, $\times 500$.

1 - simple columnar epithelium, 2-mitotic divisions, 3 - mucous membrane.

Fig. 19. Fragment of mucous membrane in infundibulum tubae uterinae of 33month-old female (luteral phase of ovary). Haematoxylin-eosin, $\times 630$.

1 - nail-shaped cells, 2 - ciliated columnar cells, 3 - blood-vessels.

Fig. 20. Section through isthmus tubae uterinae of 6-month-old female. Orcein staining for elastic fibres, $\times 125$.

1 - epithelium, 2 - mucous membrane, 3 -layer of circular muscular tunic, 4layer of longitudinal muscular tunic, 5 - ligament.

Fig. 21. Mucous membrane of uterine tube of nursing female. Mallory, $\times 250$.

Plate IX

Fig. 22. Uterus of newborn female: A - section of uterine horn, $\times 50, B-f r a g-$ ment of mucous membrane, $\times 500$. Mallory.

1 - mucous membrane, 2 - muscular membrane, 3 -fragment of uterine mesentery, 4 - characteristic fold of mucosa.

Fig. 23. Cervix uteri of 6-month-old female: A-cross section, $\times 20, B-$ fragment of mucous membrane, $\times 500$. Haematoxylin-eosin.

1 - lumen of canales cervicis, 2-septum, 3-mucous membrane, 4-layer of circular muscular tunic, 5 - layer of longitudinal muscular tunic.

Plate $\mathrm{X}$

Fig. 24. Section through mucosa cervix uteri of newborn female. Buds of uterine glands visible. Haematoxylin-eosin, $\times 250$. 
Fig. 25. Uterine glands: A - in follicular phase of ovary of female No. 12. Mallory, $\times 250, B-$ in luteal phase of ovary of female No. 13, haematoxylin-eosin, $\times 350$, $\mathrm{C}-$ pregnant female which died at parturition, Mallory, $\times 600$.

\section{Plate XI}

Fig. 26. Mucous membrane of vagina: A - in 4-month-old female, B - in 6-monthold female, C - in pregnant female, follicular phase of ovary, D-pregnant female with resorption of foetuses. A, B, C $-\times 500, D-\times 800$. Staining: A and C haematoxylin-eosin, $\mathrm{B}$ and $\mathrm{D}-$ Doboszyńska's method.

Fig. 27. Elastic fibres of corpus clitoridis. Orcein, $\times 500$.

\section{Plate XII}

Flg. 28. General picture of clitoris (ventral side), $\times 5$.

1 - glans, 2-lateral preputial folds, 3 - ventral preputial folds, 4 - pigmentation, 5 - preputial cavity.

Fig. 29. Section through glans clitoridis: A - fragment of glans and preputial fold, $\times 40, B-$ corpus cavernosum of clitoris, $\times 100$. Haematoxylin-eosin.

Fig. 30. Mucous membrane of pseudocloaca and its keratinizing epithelium. Doboszyńska's method. $\times 25$. 



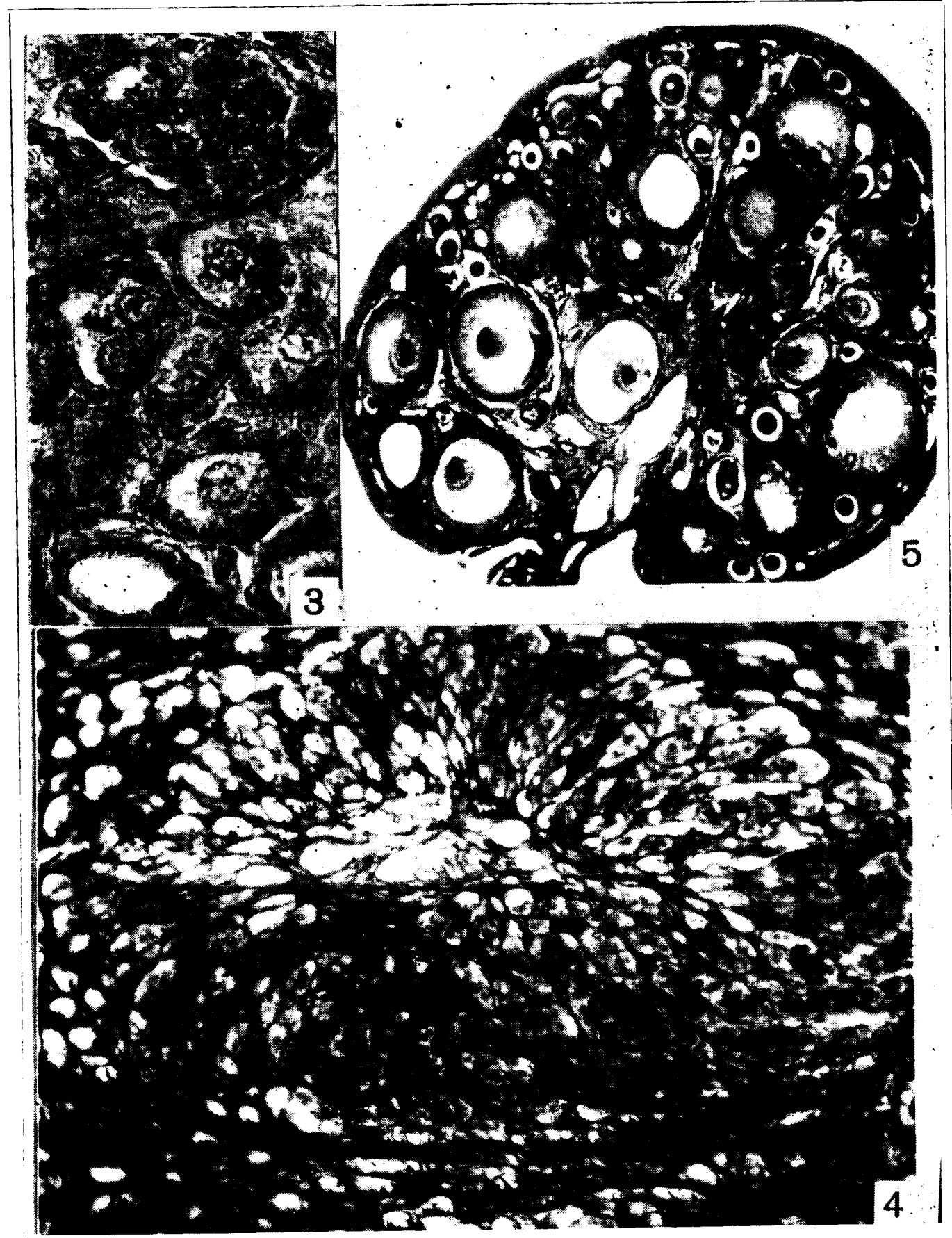



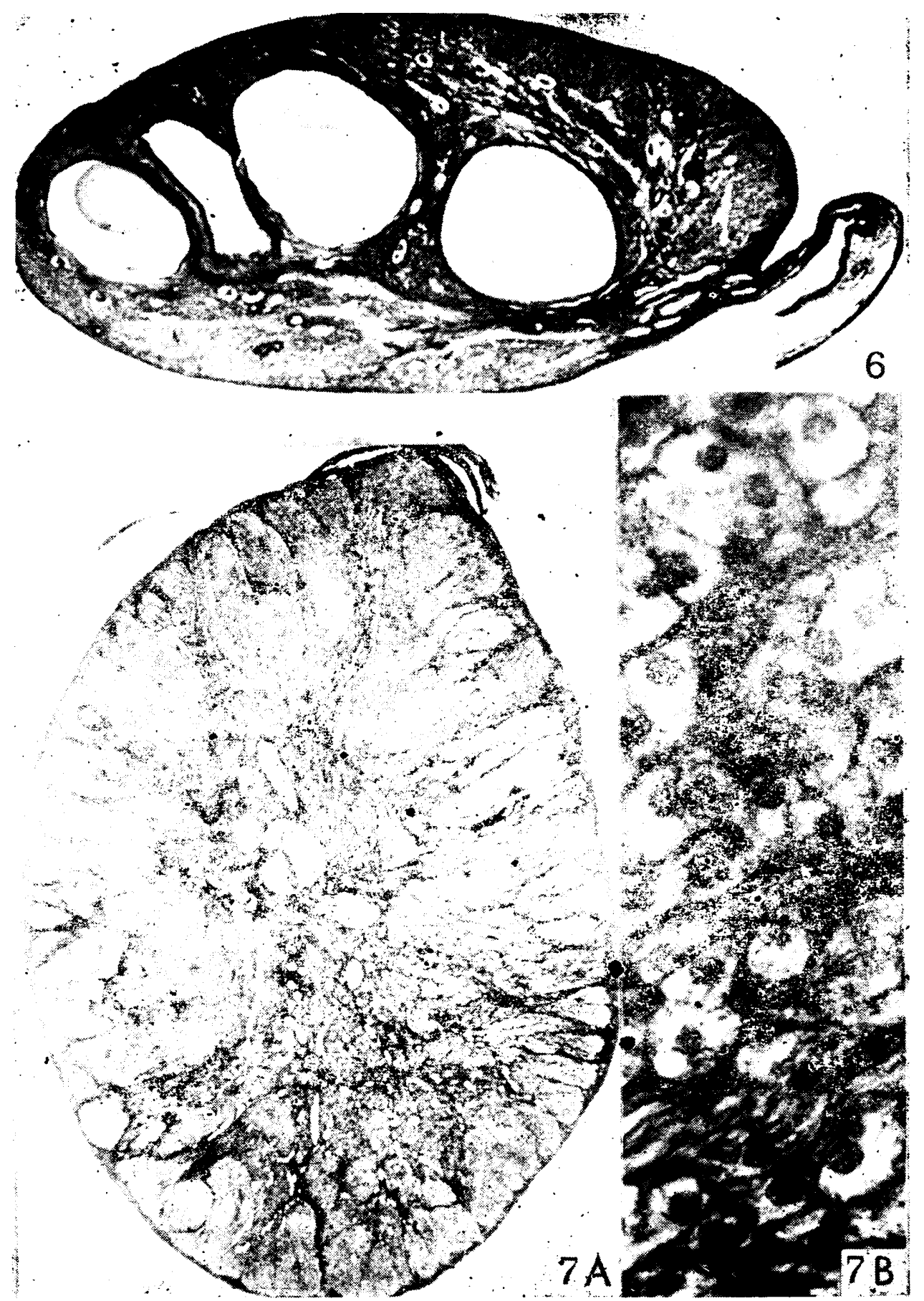

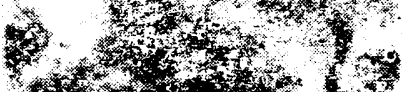

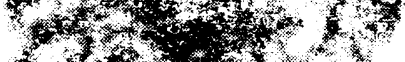
(6) $\therefore \quad 3^{2}, 3,2, y$

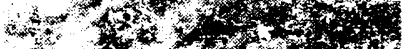
$\rightarrow \quad 3+2+34$

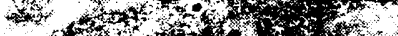

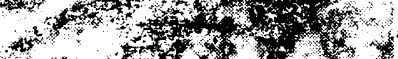

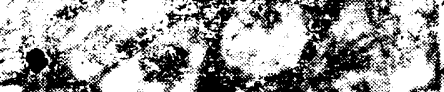

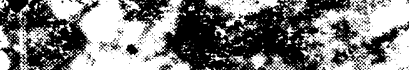

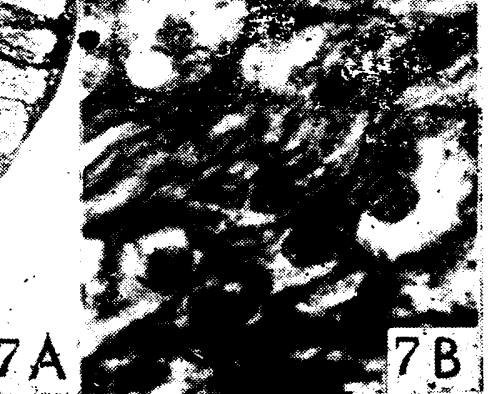




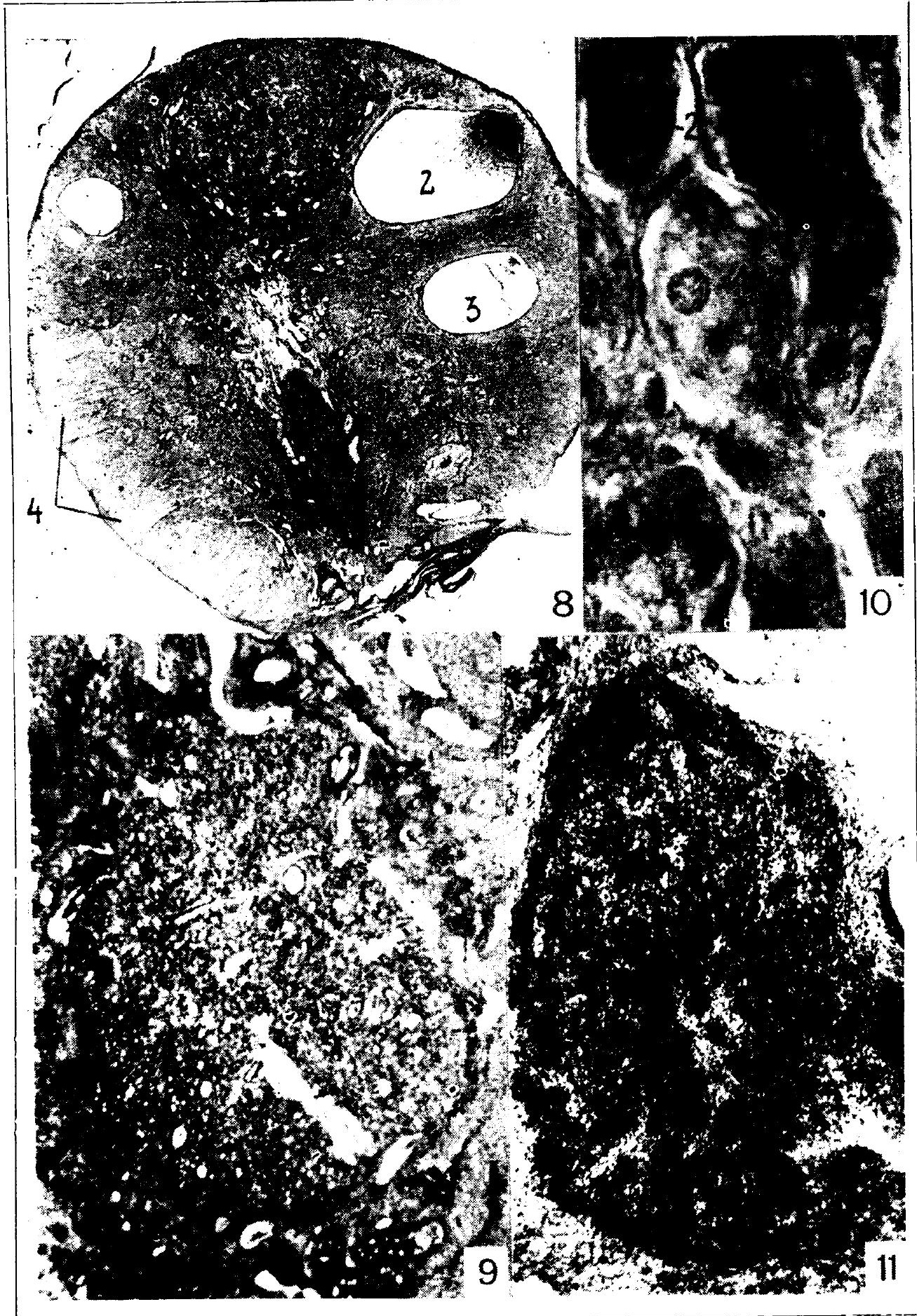




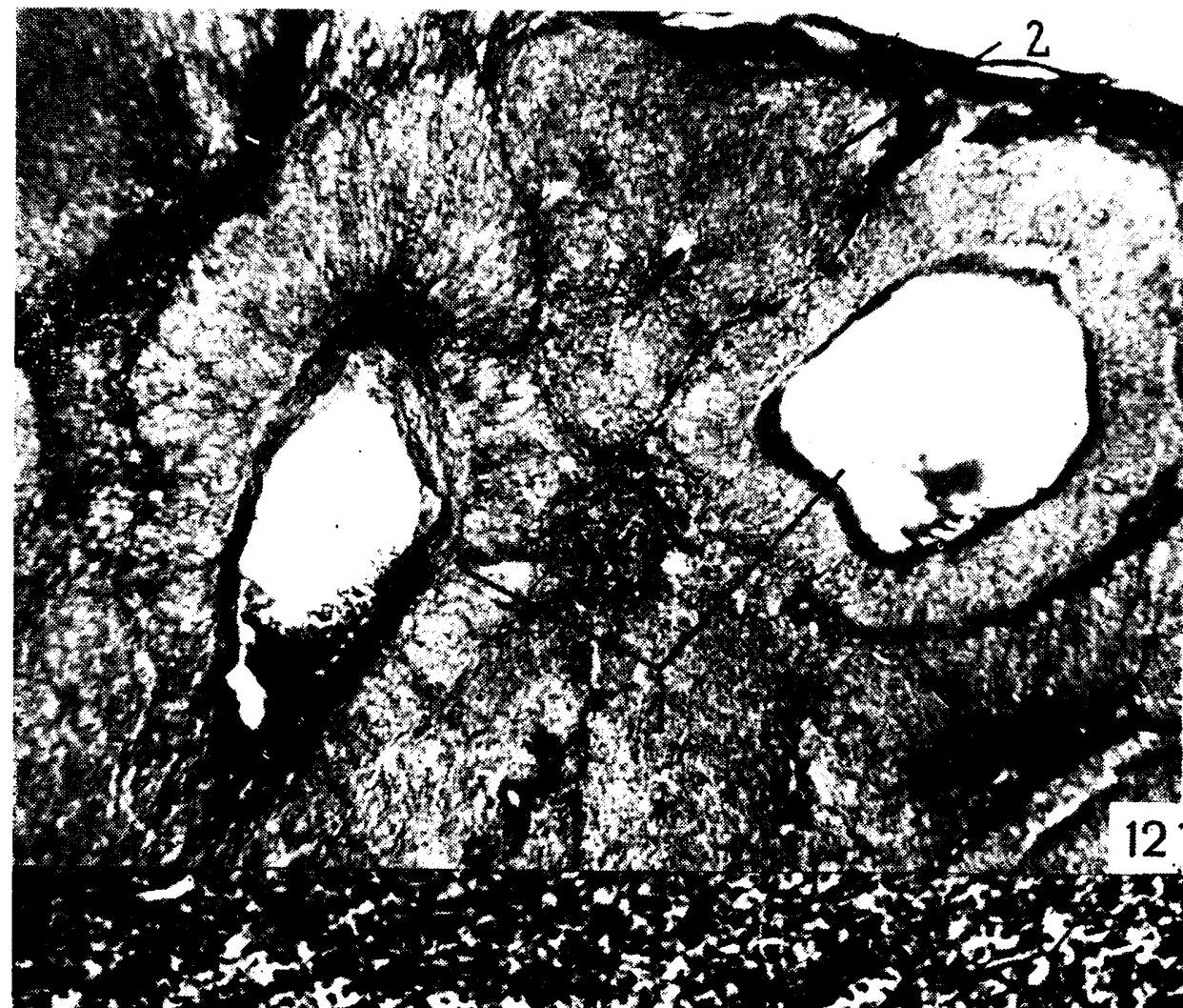

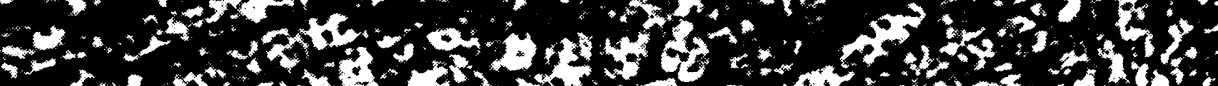

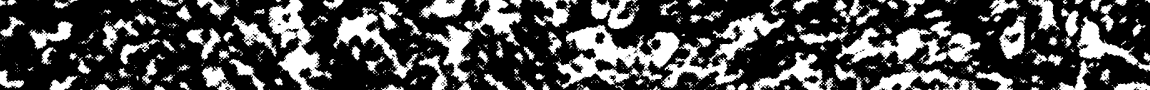

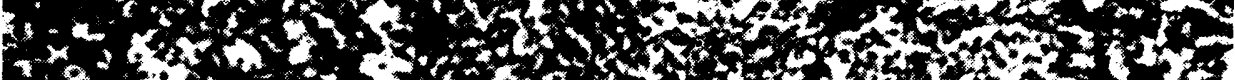

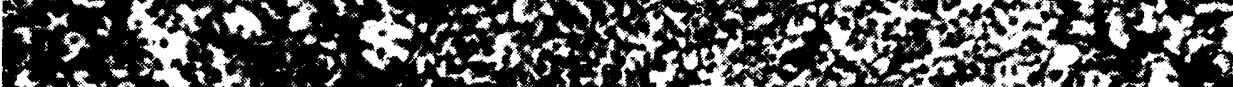

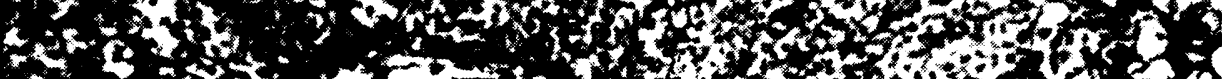

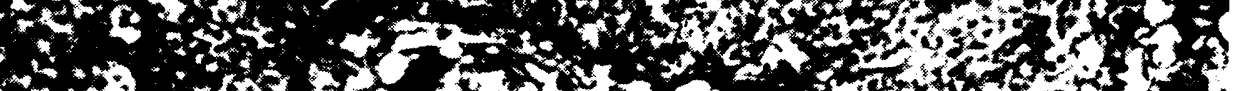

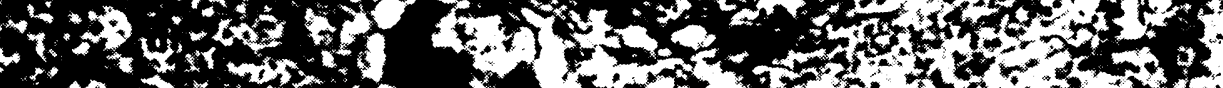

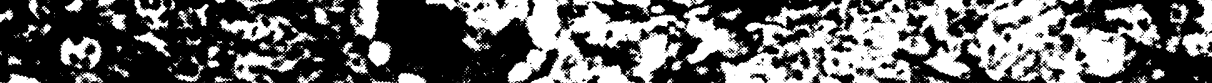

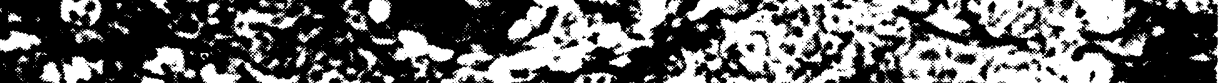

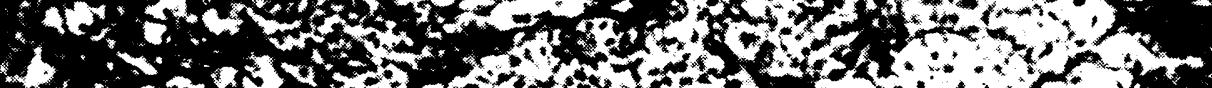

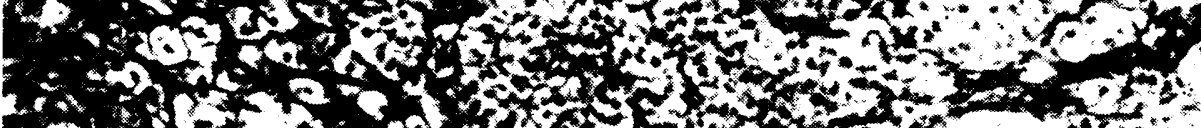

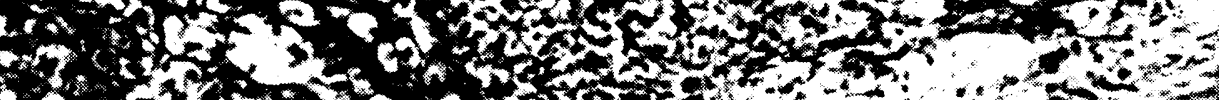

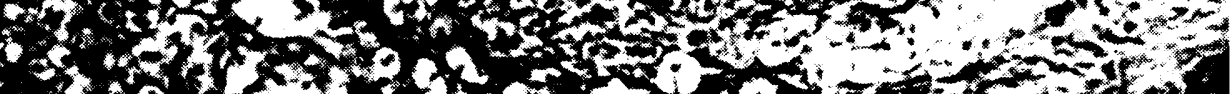

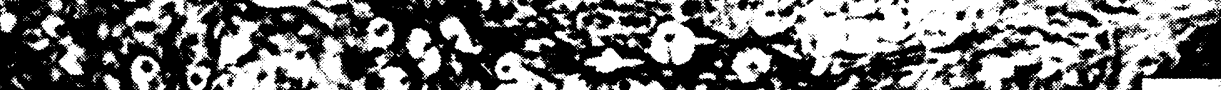

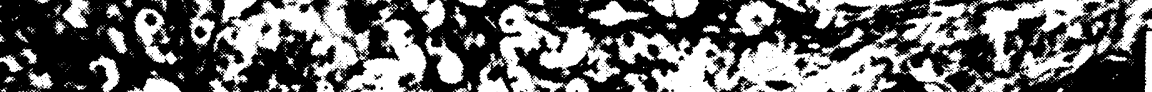
13 


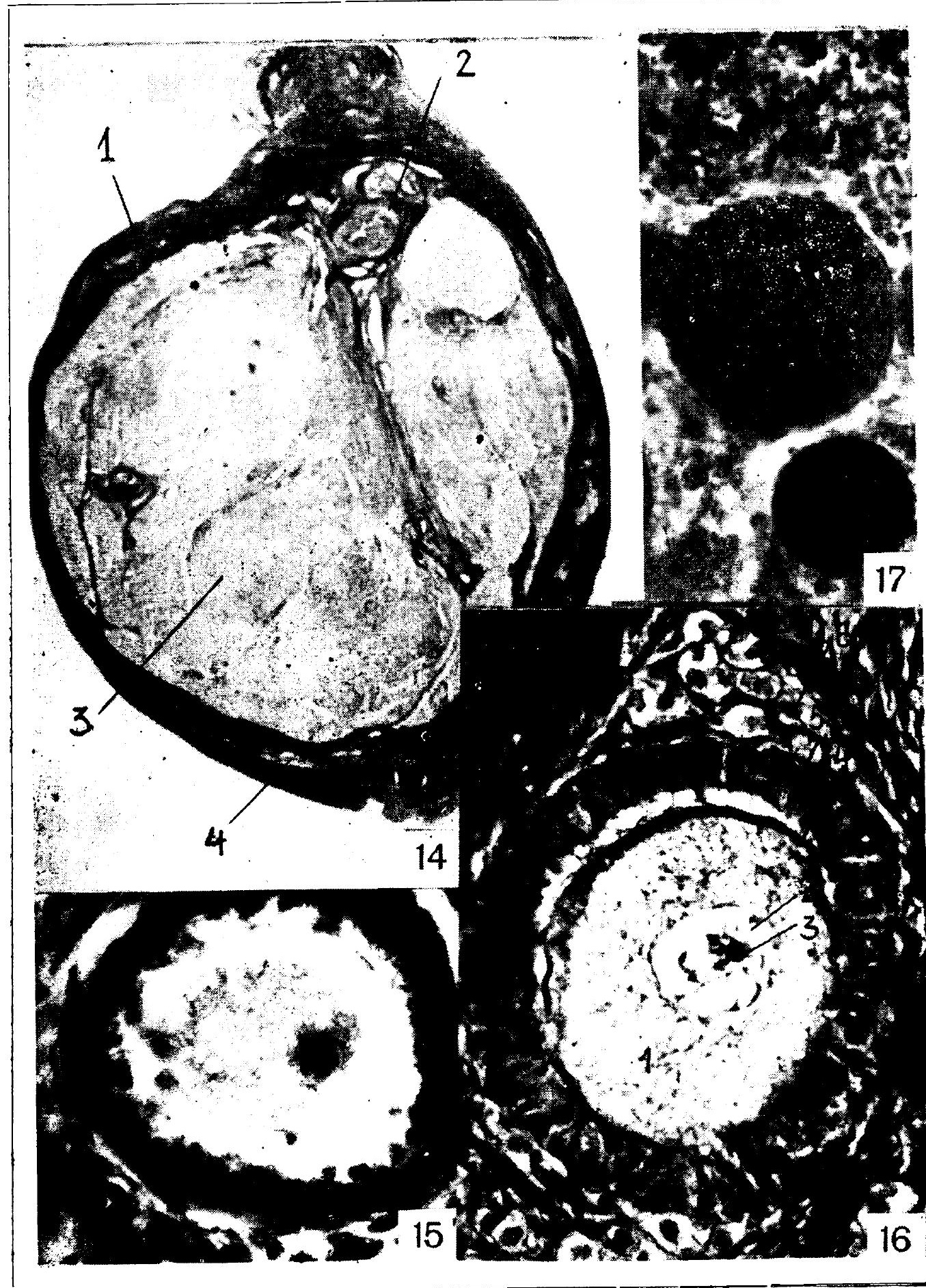




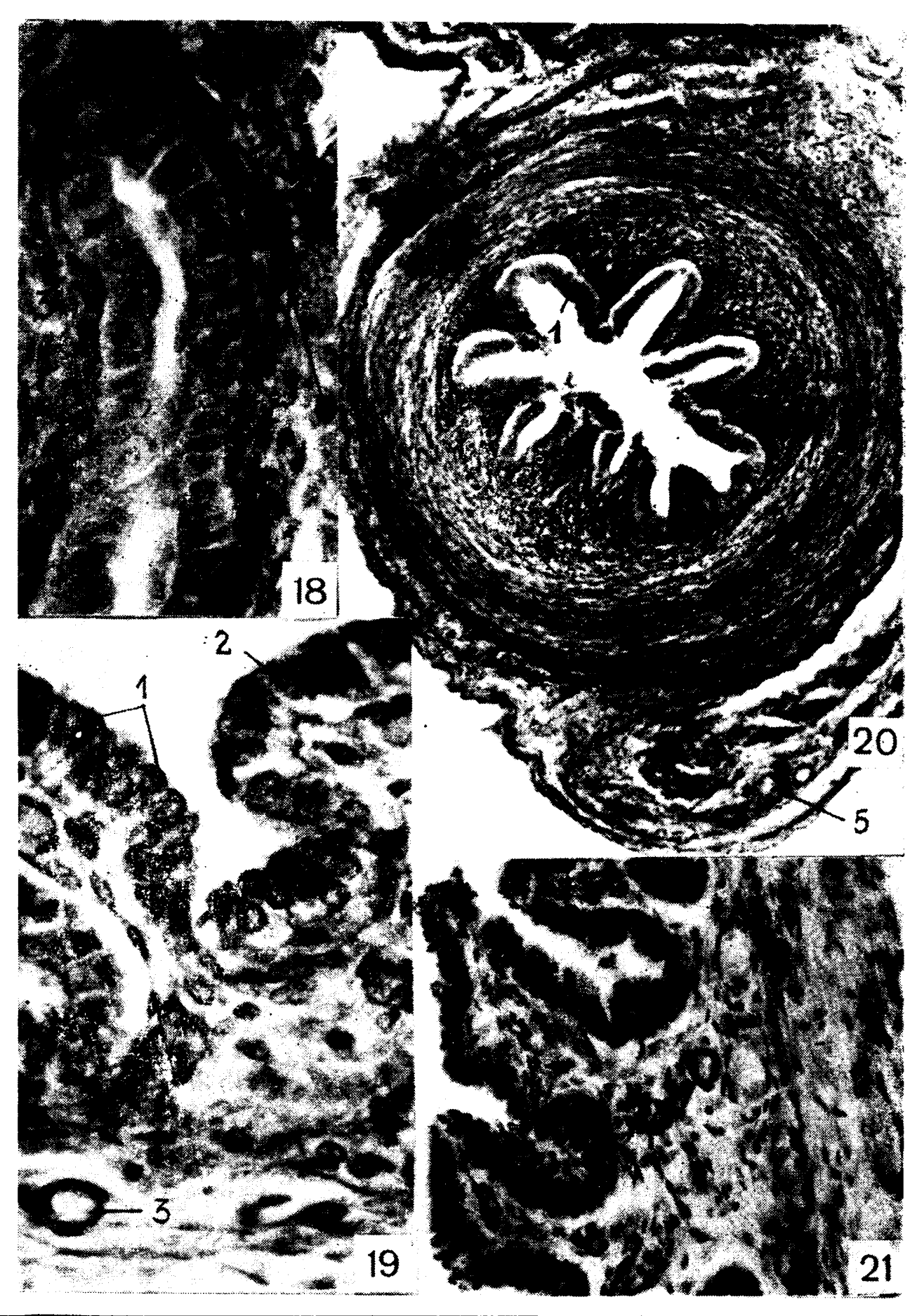

T. Doboszyńska

C. Nagięć, phot. 


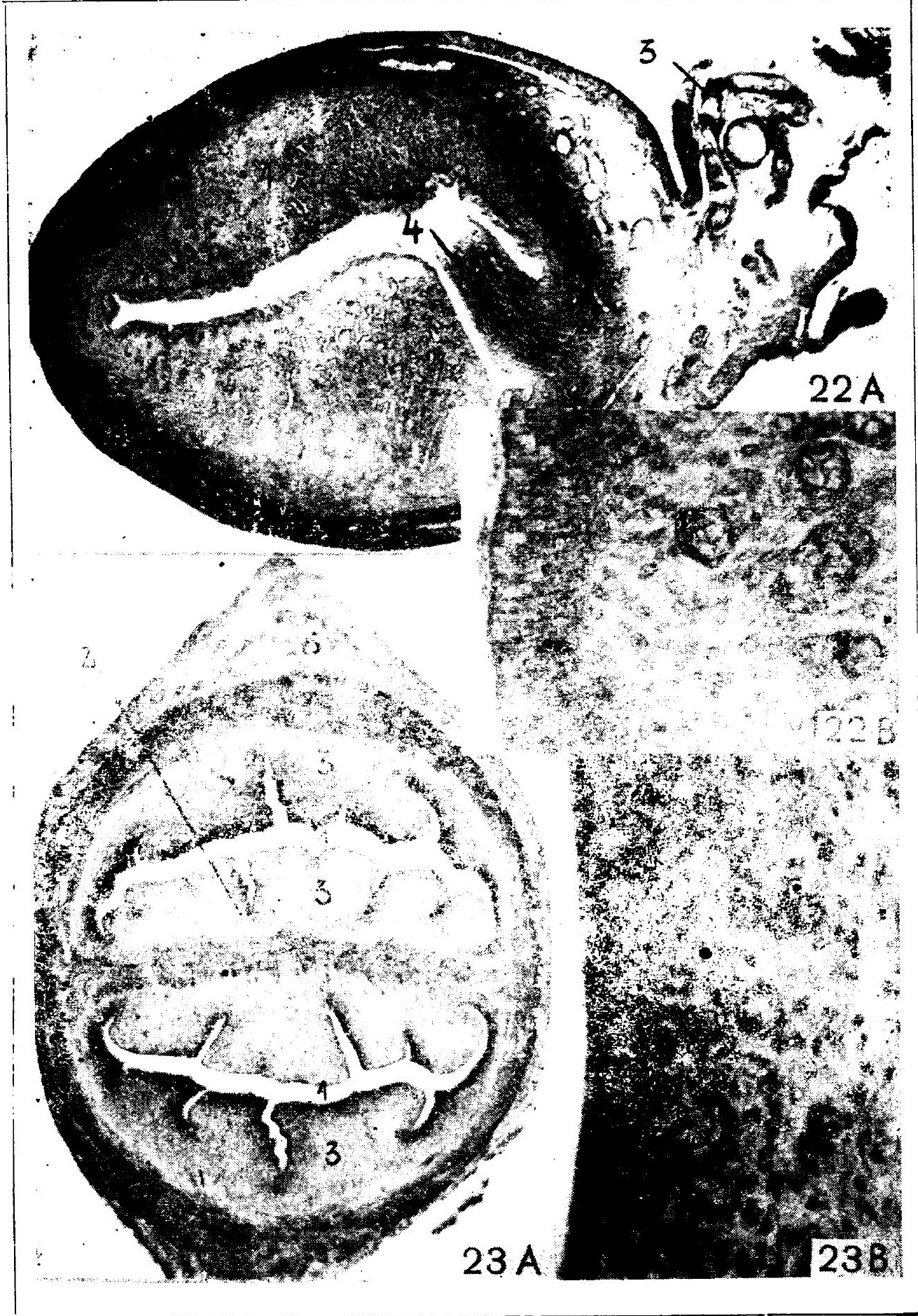



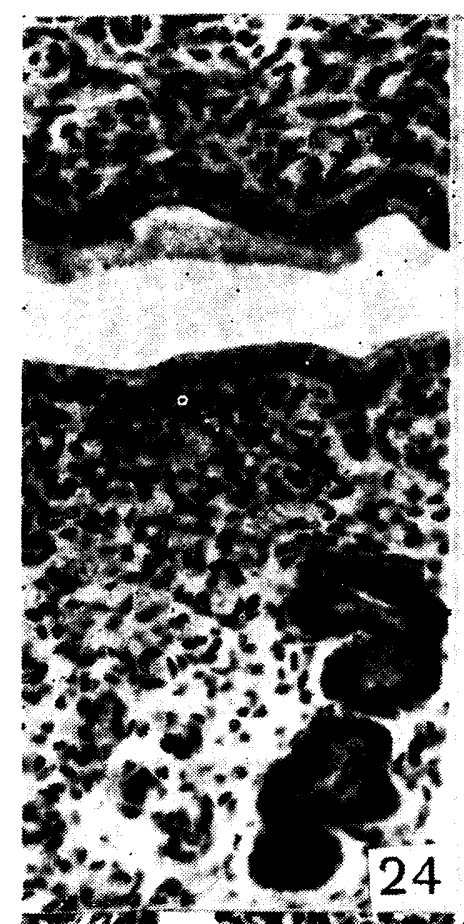

mor.

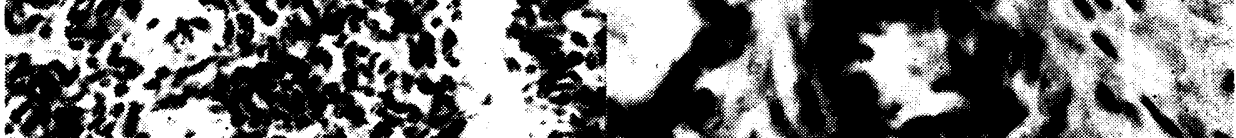

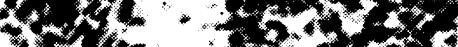

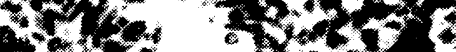

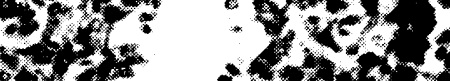

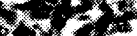

20 $3 \times$ ?

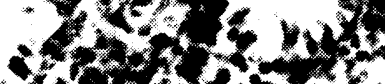

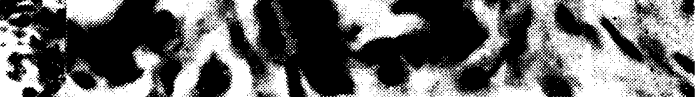

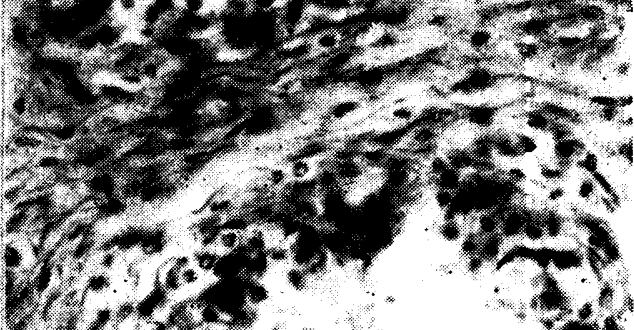

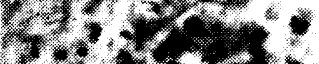

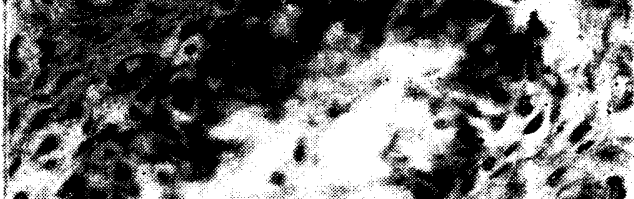

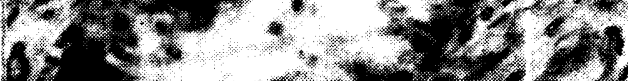

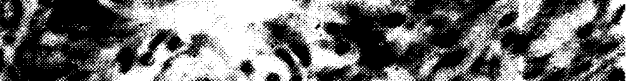

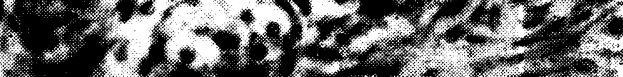

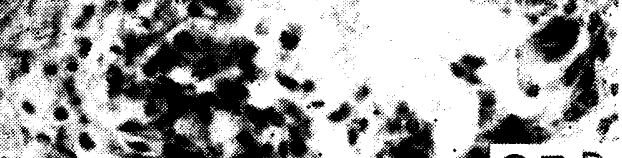

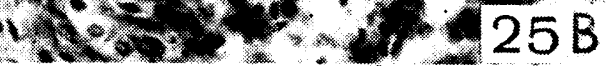

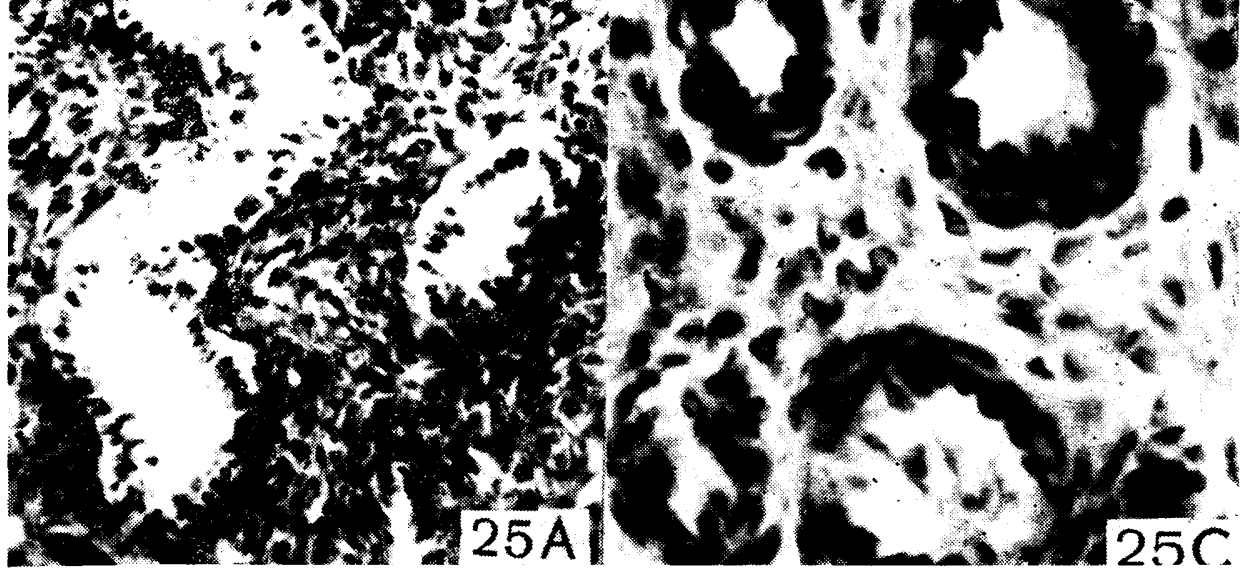




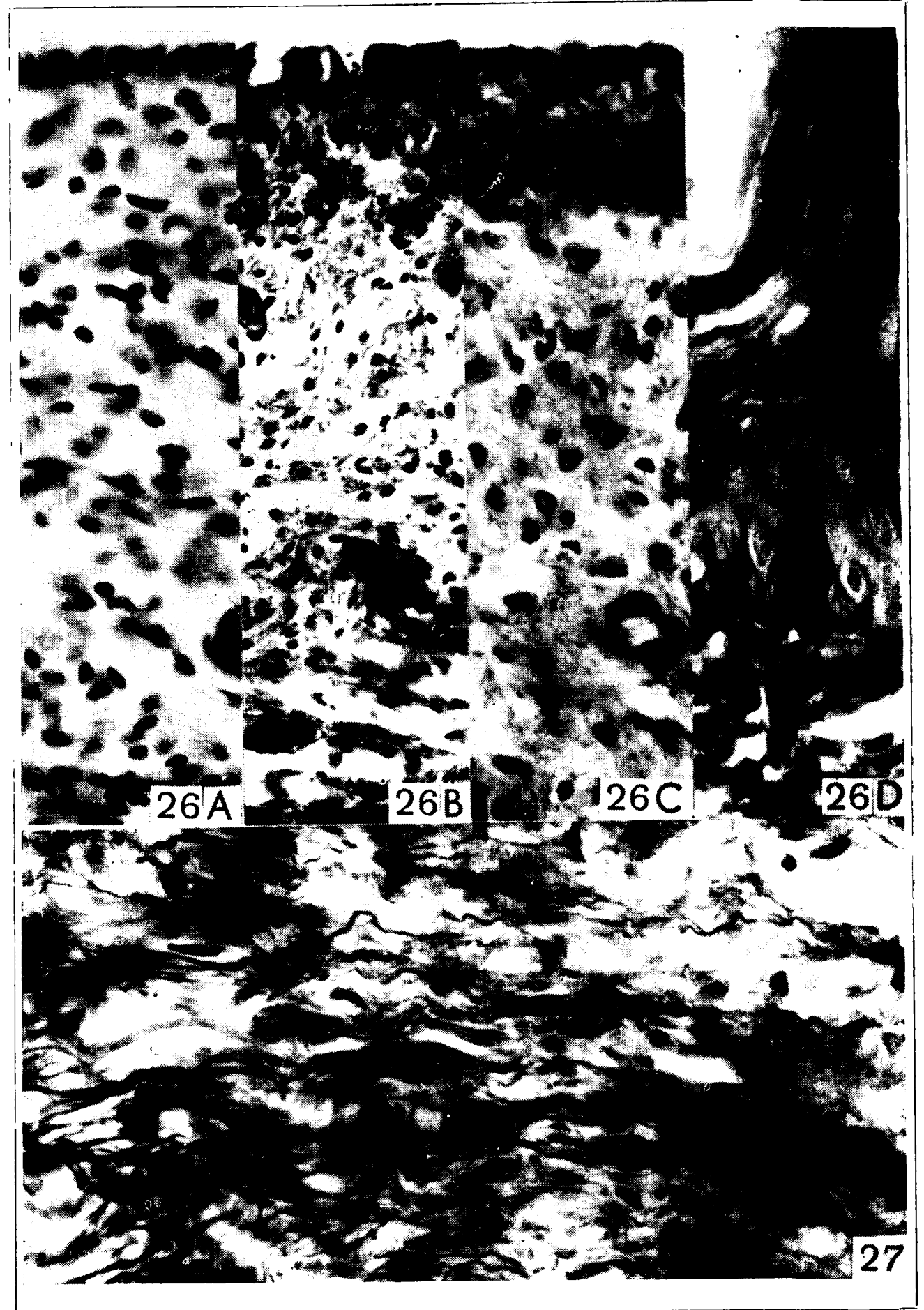




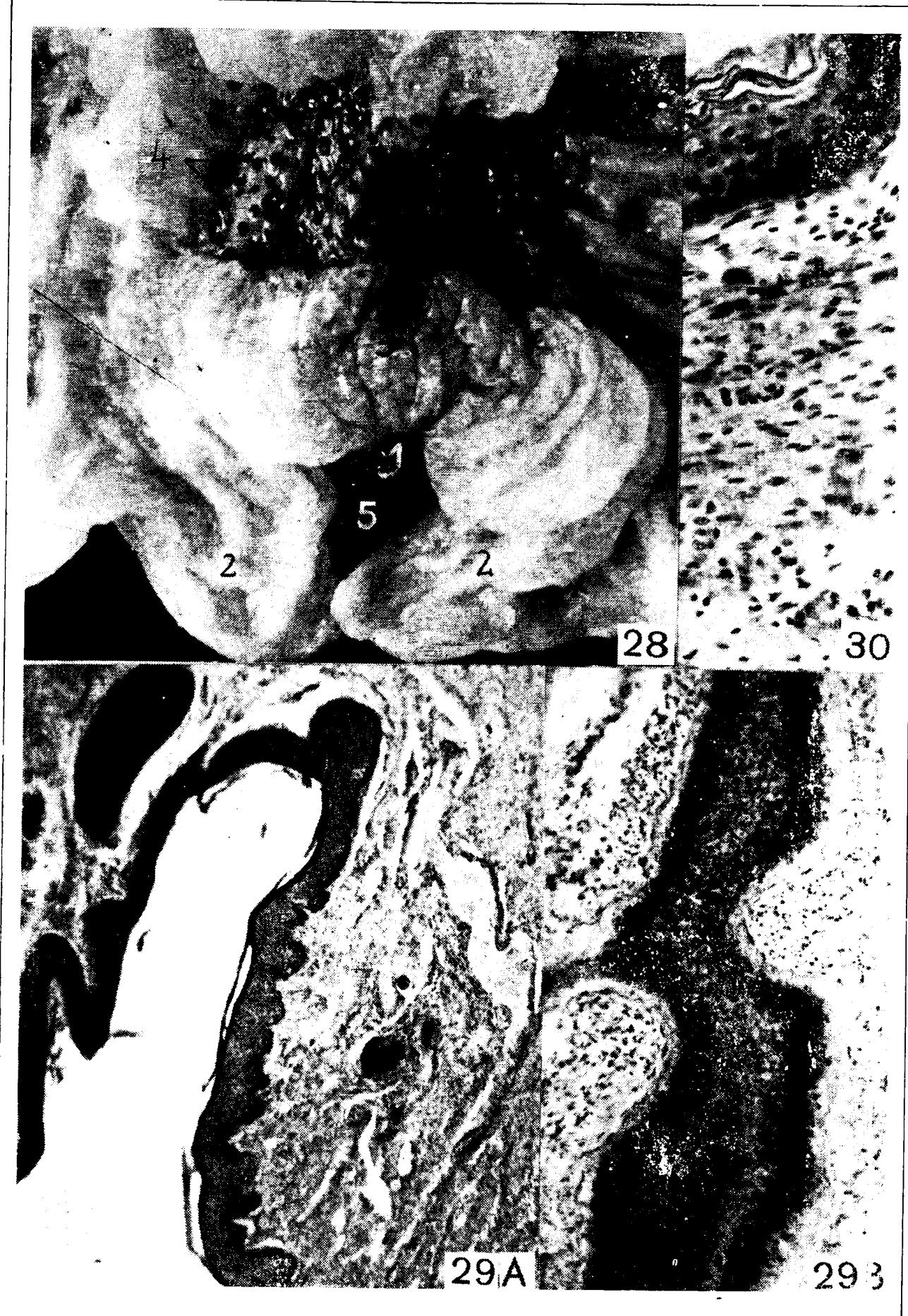

